\title{
Contrasting late-glacial paleoceanographic evolution between the upper and lower continental slope of the western South Atlantic
}

\author{
Leticia G. Luz ${ }^{1}$, Thiago P. Santos ${ }^{2}$, Timothy I. Eglinton ${ }^{3}$, Daniel Montluçon ${ }^{3}$, Blanca Ausin ${ }^{3,4}$, Negar Haghipour ${ }^{3}$, \\ Silvia M. Sousa ${ }^{5}$, Renata H. Nagai ${ }^{6}$, and Renato S. Carreira ${ }^{1}$ \\ ${ }^{1}$ LabMAM, Departamento de Química, Pontifícia Universidade Católica do Rio de Janeiro (PUC-Rio), Rio de Janeiro, Brazil \\ ${ }^{2}$ Programa de Geociências (Geoquímica), Universidade Federal Fluminense, Niterói, Brazil \\ ${ }^{3}$ Department of Earth Sciences, Geological Institute, ETH Zürich, Zürich, Switzerland \\ ${ }^{4}$ Department of Geology, University of Salamanca, Salamanca, Spain \\ ${ }^{5}$ Instituto de Oceanografia, Universidade de São Paulo, São Paulo, Brazil \\ ${ }^{6}$ Centro de Estudos do Mar, Universidade Federal do Paraná (UFPR), Paraná, Brazil
}

Correspondence: Leticia G. Luz (leticiagluz@gmail.com)

Received: 21 January 2020 - Discussion started: 6 February 2020

Revised: 1 June 2020 - Accepted: 15 June 2020 - Published: 16 July 2020

\begin{abstract}
The number of sedimentary records collected along the Brazilian continental margin has increased significantly in recent years, but relatively few are located in shallow waters and register paleoceanographic processes in the outer shelf-middle slope prior to $10-15 \mathrm{ka}$. For instance, the northward flow up to $23-24^{\circ} \mathrm{S}$ of cold and fresh shelf waters sourced from the Subantarctic region is an important feature of current hydrodynamics in the subtropical western South Atlantic Ocean, and yet limited information is available for the long-term changes of this system. Herein, we considered a suite of organic and inorganic proxies - alkenonesderived sea surface temperature (SST), $\delta \mathrm{D}$-alkenones, $\delta^{18} \mathrm{O}$ of planktonic foraminifera, and ice-volume free seawater $\delta^{18} \mathrm{O}_{\mathrm{IVF}-\mathrm{SW}}$ - in sediment from two cores (RJ-1501 and RJ1502) collected off the Rio de Janeiro Shelf (SE Brazilian continental shelf) to shed light on SST patterns and relative salinity variations since the end of the last glacial cycle in the region and the implications of these processes over a broader spatial scale. The data indicate that, despite the proximity ( $\sim 40 \mathrm{~km}$ apart) of both cores, apparently contradictory climatic evolution occurred at the two sites, with the shallower (deeper) core RJ-1501 (RJ-1502) showing consistently cold (warm) and fresh (salt) conditions toward the Last Glacial Maximum (LGM) and last deglaciation. This can be reconciled by considering that the RJ-1501 core registered a signal from mid- to high latitudes on the upper slope off
\end{abstract}

Rio de Janeiro represented by the influence of the cold and fresh waters composed of Subantarctic Shelf Water and La Plata Plume Water transported northward by the Brazilian Coastal Current (BCC). The data from core RJ-1502 and previous information for deep-cores from the same region support this interpretation. In addition, alkenone-derived SST and $\delta^{18} \mathrm{O}_{\mathrm{IVF}-\mathrm{SW}}$ suggest a steep thermal and density gradient formed between the BCC and Brazil Current (BC) during the last climate transition which, in turn, may have generated perturbations in the air-sea heat flux with consequences for the regional climate of SE South America. In a scenario of future weakening of the Atlantic Meridional Overturning Circulation, the reconstructed gradient may become a prominent feature of the region.

\section{Introduction}

The paleoclimatic knowledge accessed through marine sediment cores from the extensive Brazilian continental margin has increased significantly through the last decades (e.g., Arz et al., 1999, 2001; Chiessi et al., 2008; Govin et al., 2014; Jaeschke et al., 2007; Jennerjahn et al., 2004; Lessa et al., 2017; Mulitza et al., 2017; Portilho-Ramos et al., 2015; Rühlemann et al., 1999). The records distributed along the western South Atlantic display considerably het- 
erogeneous features in terms of sedimentation rate and response to the adjacent continental climate, which makes the scientific outputs extremely dependent on the core site location. Those cores located adjacent to the semiarid NE Brazil allowed several investigations addressing the interplay between changes in the Atlantic Meridional Overturning Circulation (AMOC), the sea surface temperature (SST) of the tropical Atlantic, and the continental climate (in terms of precipitation and vegetation cover) in centennial to millennial timescales (Behling et al., 2000; Bouimetarhan et al., 2018; Burckel et al., 2015; Crivellari et al., 2019; Venancio et al., 2018; Zhang et al., 2015, 2017). Otherwise, marine records recovered from the subtropical realm (south of $20^{\circ} \mathrm{S}$ ) generally do not show obvious sea surface millennial-scale features like those from NE Brazil (Santos et al., 2017a); nonetheless, this area suffers large changes in the winddriven upwelling patterns, with consequences for regional upper-ocean productivity (Lessa et al., 2019; Portilho-Ramos et al., 2019). The subtropical Brazilian margin may also be a sensitive region to the transmission of the Agulhas rings to the western South Atlantic at the end of glacial periods, highlighting its importance for glacial-interglacial transitions (Santos et al., 2017b; Ballalai et al., 2019). Similarly, the application of cores in the subtropical margin is exceptional in exploring changes in the water mass composition of the deep Atlantic during the last glacial cycle (Howe et al., 2018; Lund et al., 2015; Oppo et al., 2015; Tessin and Lund, 2013).

Most of these studies were based on intermediate to deepwater cores $(>1500 \mathrm{~m})$ recovered from the mid- to lowercontinental slope, and investigations supported by shallower water-depth cores $(<1000 \mathrm{~m})$ are generally limited to the Holocene (e.g., Albuquerque et al., 2016; Lessa et al., 2016; Nagai et al., 2014). Such a shorter time range from shallowwater cores is due to the fact that wide regions of the continental shelf were exposed during the last glacial cycle and that the sea-level rise of the last deglaciation provoked massive sedimentological disturbances, preventing the acquisition of well-organized chronological sequences. This hindrance was partially circumvented by cores GeoB2107-3 and GeoB6211-2, retrieved at 1048 and $657 \mathrm{~m}$, respectively, in which dinocyst assemblage reconstructions were developed (Gu et al., 2017, 2018). These authors verified the presence of eutrophic taxa along the SE Brazilian coast from the late glacial to the last deglaciation and assigned this to the high input of continental nutrients carried by the Brazilian Coastal Current (BCC) that flowed farther from the shore due to the low sea-level. However, a more straightforward hydrographic reconstruction of the eventual influence of the $\mathrm{BCC}$ along the southern portion of the Brazilian continental margin is still lacking. This limits the elaboration of detailed knowledge about the regional climatic evolution, mainly for inner parts of the continental margin that might receive the influence of the BCC.
Herein, the data of organic (alkenones-derived SST and $\delta \mathrm{D}$-alkenones) and inorganic $\left(\delta^{18} \mathrm{O}\right.$ of planktonic foraminifera and ice-volume free seawater $\delta^{18} \mathrm{O}_{\text {IVF-SW }}$ ) proxies obtained from two sediment cores collected in the upper (RJ-1501, $328 \mathrm{~m}$ water depth) and lower (RJ-1502, $1598 \mathrm{~m}$ water depth) continental slope in the SE Brazilian continental margin are presented. In the region of the cores, the influence of the $\mathrm{BCC}$ and $\mathrm{BC}$ results in a complex and dynamic circulation pattern (Fig. 1). The aim is to reconstruct the BCC evolution during the last glacial-interglacial transition and place it in the context of the offshore waters influenced by the BC. The data presented herein are intended to increase the knowledge of long-term circulation changes in the south and southeastern continental margin and highlight the nonlinearity of the climate system in the mid- to high South Atlantic latitudes, including insights from both the marine and continental realms.

\section{Material and methods}

\subsection{Regional settings}

The current study was carried out with sediment cores collected from the upper and intermediate slopes of the state of Rio de Janeiro, Santos Basin, located in the subtropical western South Atlantic (Fig. 1). The offshore circulation in the area is governed by the western portion of the anticyclonic movement of the South Atlantic Subtropical Gyre. The South Equatorial Current reaches the Brazilian margin and is distributed into two surface flows, at approximately $10-15^{\circ} \mathrm{S}$, namely the North Brazil Current and the BC (Peterson and Stramma, 1991; Stramma and England, 1999). The BC flows south along the Brazilian margin with a total width of 400-500 m, carrying the nutrient-poor Tropical Water (TW: $T>20^{\circ} \mathrm{C} ; S>36$ ) in its upper $\sim 100 \mathrm{~m}$ and the nutrient-rich South Atlantic Central Water (SACW: $T=6-$ $20^{\circ} \mathrm{C} ; S \sim 34.6-36$ ) between $\sim 100$ and $600 \mathrm{~m}$ water depths (Silveira et al., 2017). At $33-38^{\circ} \mathrm{S}$, the southward flow of the $\mathrm{BC}$ meets the northward flow of the Malvinas Current to form the Brazil-Malvinas Confluence (Fig. 1). The position of the Brazil-Malvinas Confluence presents a strong seasonality, moving to a lower latitude $\left(\sim 34^{\circ} \mathrm{S}\right)$ with a northward penetration of the Malvinas Current during the austral winter and a higher latitude $\left(\sim 40^{\circ} \mathrm{S}\right)$ with a southward penetration of the BC during the austral summer (Olson et al., 1988). Both the BC and Malvinas Current are deflected eastward at the Brazil-Malvinas Confluence region, feeding the South Atlantic Current.

Over the continental shelf of the subtropical western South Atlantic, water masses are originated by the dilution of open ocean waters from the western boundary currents. Two distinct water masses are identified, the cold and low-salinity Subantarctic Shelf Water and the warm and high-salinity Subtropical Shelf Water (Piola et al., 2008). The origin of the Subantarctic Shelf Water is related to precipitation excess 

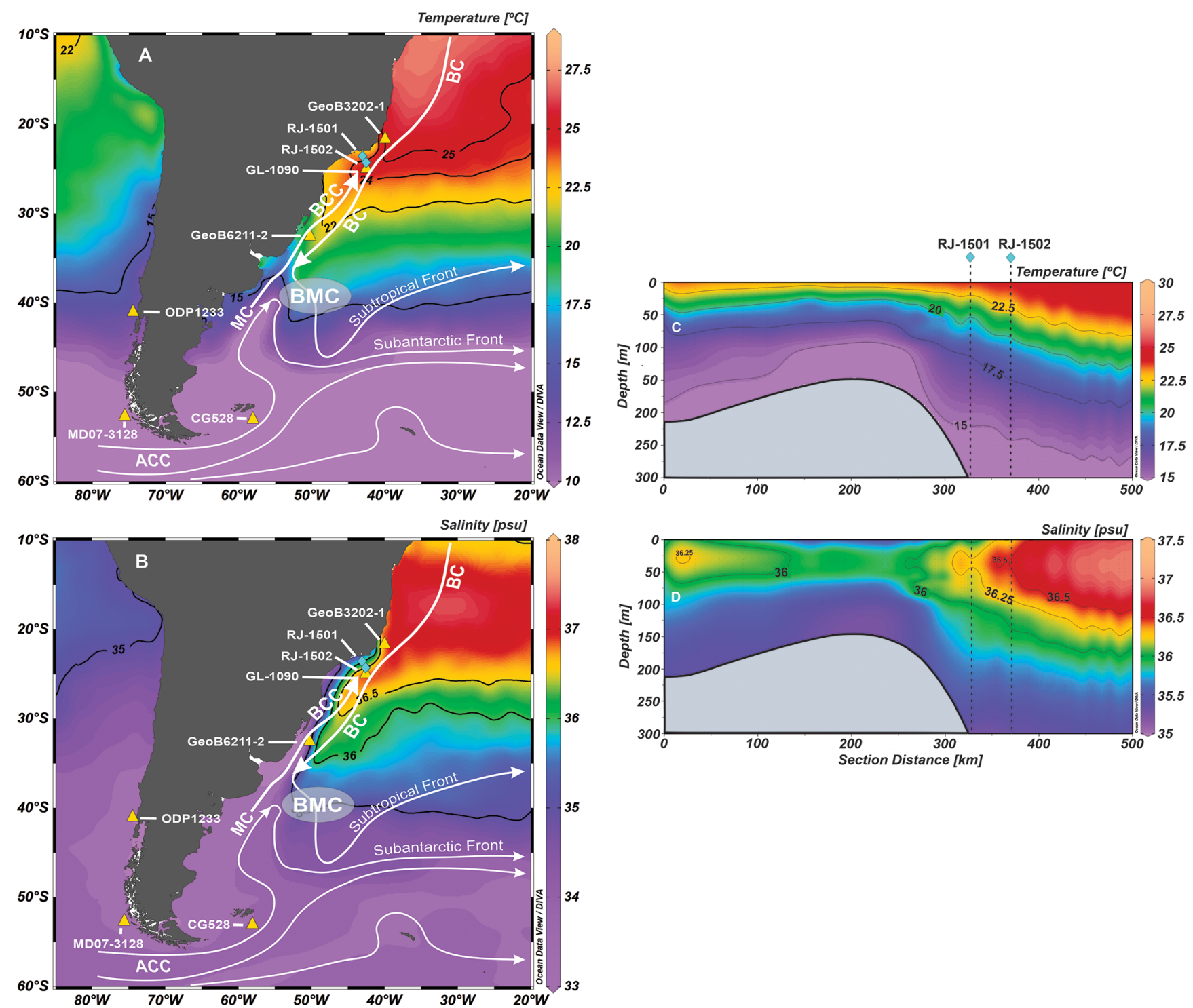

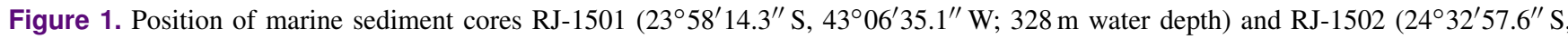
$42^{\circ} 55^{\prime} 42.9^{\prime \prime} \mathrm{W}$; $1598 \mathrm{~m}$ water depth) in the upper and lower continental slope of the subtropical western South Atlantic and other cores (GeoB3202-1, GL-1090, GeoB6211-2, CG528, MD07-3128, and ODP1233) discussed in this study. The maps feature the annual (a) sea surface temperature and (b) sea surface salinity. The transects on panels (c) and (d) show the annual water mass structure relative to temperature and salinity, respectively. Acronyms on panels (a) and (b) define the Brazil Current (BC), Brazilian Coastal Current (BCC), Malvinas Current (MC), Brazil-Malvinas Confluence (BMC), and Antarctic Circumpolar Current (ACC). Temperature and salinity grids are derived from the World Ocean Atlas 2013 (Locarnini et al., 2013; Zweng et al., 2013). This figure was produced using the software Ocean Data View (Schlitzer, 2017).

and continental runoff in the southeast Pacific that penetrates the South Atlantic south of Cape Horn, flowing northward. The Subtropical Shelf Water is fed by the detachment of the $\mathrm{TW}$ from the surface layer of the BC. At $\sim 33^{\circ} \mathrm{S}$, a narrow frontal zone, referred to as the Subtropical Shelf Front, separates the two water masses (Piola et al., 2000). A cross-shelf section indicates no penetration of the Subantarctic Shelf Water north of Subtropical Shelf Front, yet hydrographic and satellite observations indicate that cold $\left(14-17^{\circ} \mathrm{C}\right)$ and low-salinity (33.0-34.0) water tongues can be traced to latitudes as low as $23^{\circ} \mathrm{S}$ (Campos et al., 1996). This low-SST and low-salinity water observed beyond the front is associated with the northward spreading of La Plata River outflow (Möller et al., 2008). The discharge of the so-called Plata Plume Water produces a major impact on vertical stratification, since northward penetration of the river plume is associated with decreased surface salinity (Palma et al., 2008; Piola et al., 2005). 
Along the southern Brazilian margin, the northward movements of the Subantarctic Shelf Water and Plata Plume Water are determined by the BCC. The BCC is a seasonal coastal current flowing northward at the continental shelf from the Argentinean Shelf and southern Brazilian Shelf that transport a mixture of cold and low-salinity Plata Plume Water (generated by the discharge of La Plata River) and Subantarctic Shelf Water (derived from the northern extension of the Malvinas Current) (Möller et al., 2008; de Souza and Robinson, 2004). The BCC is forced by the prevailing southern winds allied to the meridional oscillations of the BrazilMalvinas Confluence (Stevenson et al., 1998). The cold and low-salinity BCC exhibits highly contrasting hydrographic patterns compared to those of the warm and high-salinity Brazil Current (BC) (Mendonça et al., 2017). As a consequence, the presence of the BCC over the continental shelf produces a cross-shelf SST gradient of $\sim 1.5^{\circ} \mathrm{C}$ toward the shelf break, where BCC waters meet the opposite flow of the BC. The gradient imposed by this thermal front may disturb atmospheric properties, such as surface wind stress, stability, and air-sea flux exchange, as the sea surface in this region can act as a heat source to the atmosphere (Pezzi et al., 2016).

\subsection{Sediment cores}

Gravity cores RJ-1501 ( $23^{\circ} 58^{\prime} 14.3^{\prime \prime} \mathrm{S}, 43^{\circ} 06^{\prime} 35.1^{\prime \prime} \mathrm{W}$; water depth: $328 \mathrm{~m}$; length: $402 \mathrm{~cm})$ and RJ-1502 (24 32'57.6 $\mathrm{S}$, $42^{\circ} 55^{\prime} 42.9^{\prime \prime} \mathrm{W}$; water depth: $1598 \mathrm{~m}$; length: $250 \mathrm{~cm}$ ) were collected from the slope off southeast Brazilian continental margin by RV Inspector II in June 2015 (Fig. 1). Due to the chronological limitation of ${ }^{14} \mathrm{C}$ dating, only the first $250 \mathrm{~cm}$ of the RJ-1502 core was considered in this study. Both cores were sliced at $3 \mathrm{~cm}$ intervals, resulting in 134 and 84 samples for cores RJ-1501 and RJ-1502, respectively. Samples were stored frozen in an aluminum container and subsequently freeze-dried.

\subsection{Age model}

The RJ-1501 and RJ-1502 core chronologies were obtained through accelerator mass spectrometry (AMS) ${ }^{14} \mathrm{C}$ dating over the shells of the surface-dwelling planktic foraminifera Globigerinoides ruber and Trilobatus sacculifer. The AMS ${ }^{14} \mathrm{C}$ was measured in 10 and 8 samples of core RJ-1501 and RJ-1502, respectively (Table 1). Each sample comprised roughly $10 \mathrm{~cm}^{3}$ of sediment, and 50 shells of the mentioned species were handpicked using a stereomicroscope from the $250 \mu \mathrm{m}$ size fraction. AMS ${ }^{14} \mathrm{C}$ ages were determined at the ETH Laboratory of Ion Beam Physics (Zurich) using the mini radiocarbon dating System (MICADAS). This system is based on a vacuum insulated acceleration unit that uses a commercially available $200 \mathrm{kV}$ power supply to generate acceleration fields in a tandem configuration. This technique is capable of determining low ${ }^{14} \mathrm{C}$ concentrations due to the high energies employed in the particle accelerator and the magnetic and electrostatic mass analyzers (Synal et al., 2007).

The age-depth model was built using the Bacon v. 2.3 software, which uses Bayesian statistics to reconstruct Bayesian accumulation histories for sedimentary deposits (Blaauw and Christeny, 2011). The ${ }^{14} \mathrm{C}$ ages were calibrated using the IntCal13 curve (Reimer et al., 2013) and modeled with a reservoir age of $375 \pm 36$ years from 10 local records (Fig. 2). Bacon was run with default parameter settings, except for a higher memory (mem.mean $=0.7$ ) to consider that the sedimentation rate of a particular depth in the cores depends on the depth above it. Ages were modeled using Student $t$ distribution, with 33 degrees of freedom $(t . a=33, t . b=34)$ and 10000 age-depth realizations to estimate median age, and $95 \%$ confidence intervals at $3 \mathrm{~cm}$ resolutions for each core. Mean $95 \%$ confidence ranges were of 2588 and 3861 years for cores RJ-1501 and RJ-1502, respectively. One hundred percent of the dates lie within the age-depth model in a $95 \%$ range for both cores. According to our age-depth models, cores RJ-1501 and RJ-1502 cover the last 42.44 and $53.57 \mathrm{kyr}$ BP (Fig. 2). The mean sedimentation rate of core RJ-1501 was around $100 \mathrm{yr} \mathrm{cm}^{-1}$ between 40 and $20 \mathrm{ka}$, with a steep increase to $500 \mathrm{yr} \mathrm{cm}^{-1}$ during the last deglaciation and a return to previous values during the Holocene. A general lower sedimentation rate was found for core RJ1502 , with roughly $200 \mathrm{yr} \mathrm{cm}^{-1}$ between 50 and $20 \mathrm{ka}$ and almost $1000 \mathrm{yr} \mathrm{cm}^{-1}$ during the last deglaciation and Holocene (Fig. 2).

\subsection{Alkenone analyses and sea surface temperature reconstruction ( $\mathrm{U}_{37}^{\mathrm{K}^{\prime}}$-derived $\mathrm{SST}$ )}

A total of 139 sediment samples were selected for alkenone analyses, considering the two collected cores. Samples were freeze dried and homogenized with a mortar and pestle. A $15-30 \mathrm{~g}( \pm 0.1 \mathrm{mg})$ aliquot of the homogenized material was extracted in a pressurized solvent extractor system (Dione ${ }^{\circledR}$ ASE-200) using a mixture of dichloromethane (DCM) : methanol $9: 1(v / v)$ at $100^{\circ} \mathrm{C}$ and $1000 \mathrm{psi}$ in two cycles, 11 min per cycle. Before extractions, a known amount of 2-nonadecanone was added as a surrogate standard. The total lipid extracts were saponified $\left(1 \mathrm{M} \mathrm{KOH}\right.$ at $110^{\circ} \mathrm{C}$ for $2 \mathrm{~h}$ ), and the neutral fraction was recovered with $n$-hexane. The neutrals were further fractionated using a Pasteur pipette containing $4 \mathrm{~cm}$ of activated silica into three fractions: apolar ( $4 \mathrm{~mL}$ of $n$-hexane), ketones ( $4 \mathrm{~mL}$ of $n$-hexane: DCM, $2: 1 / v: v$ ), and polar (4 mL of DCM : methanol, $1: 1 / v: v$ ). The alkenone analyses were performed at the Chemistry Department from PUC-Rio. The alkenones in the ketones fraction were identified and quantified using a Thermo ${ }^{\circledR}$ FOCUS gas chromatograph equipped with an Agilent DB-5 capillary column $(60 \mathrm{~m} \times 250 \mu \mathrm{m}$ diameter $\times 0.25 \mu \mathrm{m}$ internal film $)$ and a flame ionization detector. The oven temperature program used started at $50^{\circ} \mathrm{C}$, followed by a $20^{\circ} \mathrm{C} \mathrm{min}^{-1}$ ramp up to $80^{\circ} \mathrm{C}$ and a second ramp at $8^{\circ} \mathrm{C} \mathrm{min}^{-1}$ up to $320^{\circ} \mathrm{C}$, 
Table 1. Accelerator mass spectrometer radiocarbon (MICADAS) dates and calibrated ages used for age-depth models of cores RJ-1501 and RJ-1502.

\begin{tabular}{|c|c|c|c|c|c|c|c|}
\hline Station & $\begin{array}{r}\text { Core } \\
\text { depth } \\
(\mathrm{cm})\end{array}$ & ID lab & Species & $\begin{array}{r}\text { Radiocarbon } \\
\text { Age } \\
(\mathrm{yr} \mathrm{BP})\end{array}$ & $\begin{array}{l} \pm 1 \mathrm{~s} \\
\text { error }\end{array}$ & $\begin{array}{r}\text { Calibrated } \\
\text { Age } \\
(\text { cal yr BP) }\end{array}$ & $\begin{array}{l}\text { Min-max } \\
\text { (cal yr BP) }\end{array}$ \\
\hline \multirow[t]{10}{*}{ RJ-1501 } & 2 & 82195 & G. ruber, T. sacculifer & 2168 & 65 & 1756 & $1574-1930$ \\
\hline & 5 & 84479 & G. ruber, T. sacculifer & 3647 & 118 & 3138 & 2861-3397 \\
\hline & 8 & 82194 & G. ruber, T. sacculifer & 3367 & 68 & 3361 & $3202-3558$ \\
\hline & 11 & 84478 & G. ruber, T. sacculifer & 4078 & 66 & 3904 & 3706-4094 \\
\hline & 50 & 85107 & G. ruber, T. sacculifer & 8649 & 141 & 9145 & 8705-9496 \\
\hline & 74 & 82193 & G. ruber, T. sacculifer & 9426 & 84 & 10273 & 9984-10533 \\
\hline & 101 & 84477 & G. ruber, T. sacculifer & 10614 & 83 & 12090 & $11691-12453$ \\
\hline & 119 & 82192 & G. ruber, T. sacculifer & 17050 & 126 & 19706 & $19039-20272$ \\
\hline & 290 & 82191 & G. ruber, T. sacculifer & 28270 & 282 & 31955 & $31244-32779$ \\
\hline & 323 & 84476 & G. ruber, T. sacculifer & 30927 & 280 & 34585 & $34048-35143$ \\
\hline \multirow[t]{8}{*}{ RJ-1502 } & 8 & 84509 & G. ruber, T. sacculifer & 4055 & 86 & 3841 & 3353-4239 \\
\hline & 26 & 85049 & G. ruber, T. sacculifer & 15418 & 111 & 18454 & $18123-18793$ \\
\hline & 38 & 85048 & G. ruber, T. sacculifer & 16813 & 117 & 20236 & 19903-20614 \\
\hline & 41 & 85047 & G. ruber, T. sacculifer & 18392 & 129 & 21321 & $20966-21676$ \\
\hline & 65 & 84510 & G. ruber, T. sacculifer & 21259 & 153 & 25523 & $24939-25966$ \\
\hline & 116 & 85106 & G. ruber, T. sacculifer & 26638 & 347 & 30784 & $29916-31447$ \\
\hline & 185 & 84508 & G. ruber, T. sacculifer & 34791 & 413 & 39395 & $38087-40532$ \\
\hline & 245 & 84507 & G. ruber, T. sacculifer & 49358 & 597 & 52887 & $48659-58741$ \\
\hline
\end{tabular}

with a final hold at this temperature for $33 \mathrm{~min}$. The extracts $(1 \mu \mathrm{L})$ were injected in splitless mode, and $\mathrm{He}$ was used as the carrier gas at $1.2 \mathrm{~mL} \mathrm{~min}^{-1}$. Alkenone identification was based on the retention time of authentic standards, whereas quantification followed the internal standard method using $n-\mathrm{C}_{36}$ alkane. Analytical precision was estimated as $12 \%$ or better, based on triplicate analyses of a sediment sample. The $\mathrm{U}_{37}^{\mathrm{K}^{\prime}}$ values were calculated according to Prahl and Wakeham (1987): $\mathrm{U}_{37}^{\mathrm{K}^{\prime}}=\mathrm{C}_{37: 2} /\left(\mathrm{C}_{37: 2}+\mathrm{C}_{37: 3}\right)$ and were then converted to sea surface temperature $\left(\mathrm{U}_{37}^{\mathrm{K}^{\prime}}\right.$-derived SST) using the Müller et al. (1998) calibration, as follows: $\mathrm{U}_{37}^{\mathrm{K}^{\prime}}=0.033 \mathrm{U}_{37}^{\mathrm{K}^{\prime}}$-derived SST $\left({ }^{\circ} \mathrm{C}\right)+0.069 ; r^{2}=0.98 ; n=$ $149 ; \mathrm{SD}= \pm 1.0^{\circ} \mathrm{C}$. This equation was chosen because it is derived from 149 tropical-to-subpolar eastern South Atlantic surface sediments and was already used in other studies from the same region (e.g., Ceccopieri et al., 2018).

\subsection{Planktic foraminifera oxygen $\left(\delta^{18} \mathrm{O}\right)$ and carbon $\left(\delta^{13} \mathrm{C}\right)$ isotopic compositions}

The oxygen $\left(\delta^{18} \mathrm{O}\right)$ and carbon $\left(\delta^{13} \mathrm{C}\right)$ isotopic compositions were determined in planktic foraminifera Globigerinoides ruber (white) shells from selected slices of the RJ1501 and RJ-1502 cores. Approximately $10 \mathrm{~mL}$ of sediment was sifted sequentially using two sieves (63 and $150 \mu \mathrm{m}$ meshes), handpicking the specimens. Approximately 10-15 shells $>150 \mu \mathrm{m}$ from each sample were weighed in appropriate glass vials to be injected into an automatic Kiel IV Thermo Fisher Scientific ${ }^{\circledR}$ system (automatic $\mathrm{CO}_{2}$ obtain- ment device from the analyzed carbonate, Geological Institute, ETH Zurich) for the oxygen and carbon isotopic analyses. The determination of low ${ }^{18} \mathrm{O}$ and ${ }^{13} \mathrm{C}$ isotope contributions is performed by using the respective ratios with their most abundant elements in the sample. The data were reported by the delta notation in parts per thousand and relative to the standard Vienna Pee-Dee Belemnite (VPDB). The Kiel IV carbonate device was coupled to a Thermo Fisher Scientific ${ }^{\circledR}$ Delta V Plus mass spectrometer. The carbonate generated by the shells was vacuum dissolved by applying a phosphoric acid $103 \%$ drip at a temperature of $70^{\circ} \mathrm{C}$ and directed to the mass spectrometer. The masses were calibrated with the international MS2 $\left(\delta^{18} \mathrm{O}_{\mathrm{VPDB}}=1.81 \%\right.$; $\left.\delta^{13} \mathrm{C}_{\mathrm{VPDB}}=2.13 \% ; n=14\right)$ and ISOLAB B $\left(\delta^{18} \mathrm{O}_{\mathrm{VPDB}}=\right.$ $\left.-18.59 \% ; \delta^{13} \mathrm{C}_{\mathrm{VPDB}}=10.20 \% ; n=4\right)$ standards, and all results were reported as the conventional delta notation in relation to the VPDB standard. The standard deviations were $\delta^{18} \mathrm{O}=0.061$ and $\delta^{13} \mathrm{C}=0.040$ for the MS2 standard and $\delta^{18} \mathrm{O}=0.076$ and $\delta^{13} \mathrm{C}=0.076$ for the ISOLAB B standard.

\subsection{Ocean surface salinity tracers (alkenone hydrogen isotope and ice-volume free seawater oxygen isotope)}

The ${ }^{2} \mathrm{H} /{ }^{1} \mathrm{H}$ isotopic ratios of the $\mathrm{C}_{37: 2}$ and $\mathrm{C}_{37: 3}$ alkenones ( $\delta \mathrm{D}$-alkenones) produced by haptophyte algae were used as a proxy for changes in sea surface salinity (SSS). The F2 fraction separated from the organic lipid extract (see Sect. 2.4) was used to determine the $\delta \mathrm{D}$-alkenones by 


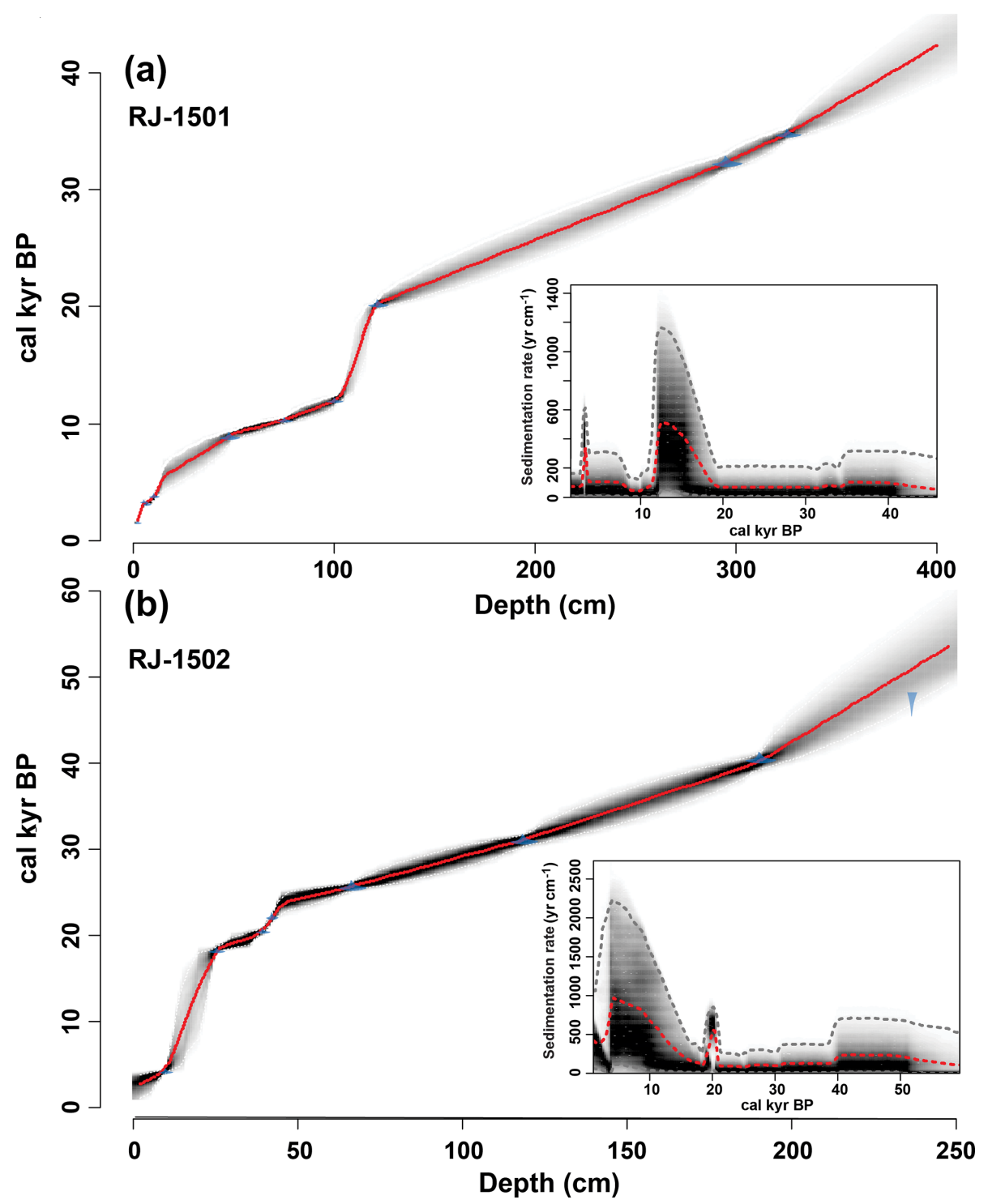

Figure 2. Bayesian age-depth model and sedimentation rate $\left(\mathrm{yr} \mathrm{cm}^{-1}\right)$ for cores (a) RJ-1501 and (b) RJ-1502. The ${ }^{14} \mathrm{C}$ ages were calibrated with the curve IntCal13 (Reimer et al., 2013) and modeled with a reservoir age of $375 \pm 36$ years from 10 local records. Thick (larger panels) and dashed (smaller panels) red lines depicted the highest probabilistic model for the ages and accumulation rate, respectively. Dashed (smaller panels) grey lines indicated the upper and bottom limits of the accumulation rate.

gas chromatography-isotopic ratio mass spectrometry (GCIRMS; Thermo TraceGC gas chromatography coupled to a Thermo Delta V Plus mass spectrometer) at the Geological Institute (ETH Zurich). A relatively large volume (up to $8 \mu \mathrm{L}$ ) of the extract, corresponding to a $50-300 \mathrm{ng}$ load of the analyte, was injected in a PTV inlet (Gerstel, CIS-6) set to the solvent-vent mode for a better quantitative transfer into an Agilent VF-1 ms column $(60 \mathrm{~m} \times 0.25 \mathrm{~mm} \times 0.25 \mu \mathrm{m})$. The oven temperature program was set to have the alkenones eluting isothermally at $300^{\circ} \mathrm{C}$ in order to minimize column bleeding. Prior to each sample injection, the high temperature pyrolysis reactor was conditioned with a $4 \mathrm{~s}$ pulse of methane through the reactor to maintain the reactor's py- rolysis efficiency (Cao et al., 2012). A standard of $n-\mathrm{C}_{27}$ alkane (Heptacosane\#3, $\delta 2 \mathrm{HVSMOW}=-172.8 \%$ o $1.6 \%$, from Arnd Schimmelmann, Biogeochemical Laboratory, Indiana University) was used to construct a calibration curve with a linear response of the IRMS signal up to $100 \mathrm{~V}$. For more intense detector signals $(>100 \mathrm{~V})$, a constant calibration offset was used. Propagated errors on duplicate analysis varied between $2 \% o$ and $8 \%$.

To determine the seawater oxygen isotope $\left(\delta^{18} \mathrm{O}_{\mathrm{sw}}\right)$, we used the G. ruber (white) $\delta^{18} \mathrm{O}$ values and $\mathrm{U}_{37}^{\mathrm{K}^{\prime}}$-derived SST applying the equation: $T\left(\mathrm{U}_{37}^{\mathrm{K}^{\prime}}\right.$-derived SST $)=-4.44$. $\left(\delta^{18} \mathrm{O}-\delta^{18} \mathrm{O}_{\mathrm{IVF}-\mathrm{SW}}\right)+14.20$ (Mulitza et al., 2003). The effect of global sea-level changes was subtracted from $\delta^{18} \mathrm{O}_{\mathrm{sw}}$ 
to generate an ice-volume free seawater $\delta^{18} \mathrm{O}\left(\delta^{18} \mathrm{O}\right.$ IVF-SW $)$ based on the sea-level reconstruction of Grant et al. (2012) and considering a glacial $\delta^{18} \mathrm{O}$ increment of 0.008 per meter sea-level lowering (Schrag et al., 2002; Simon et al., 2013). A factor of $0.27 \%$ was applied to convert the values from VPDB to Vienna Standard Mean Ocean Water (VSMOW) (Hut, 1987). The $\delta^{18} \mathrm{O}_{\text {IVF-SW }}$ uncertainty considers the uncertainty in the $\mathrm{U}_{37}^{\mathrm{K}^{\prime}}$-derived SST of $\pm 1.0^{\circ} \mathrm{C}$ - which is equivalent to a $0.22 \% \circ \delta^{18} \mathrm{O}$ change (Mulitza et al., 2003) and a $0.06 \%$ analytical error for calcite $\delta^{18} \mathrm{O}$ measurement. The total propagated cumulative uncertainty was $\pm 0.20 \%$, consistent with earlier studies that applied this proxy in the vicinity of our study area (e.g., Chiessi et al., 2015). Previous publications have used the combination of $\mathrm{U}_{37}^{\mathrm{K}^{\prime}}$-derived SST and foraminifera $\delta^{18} \mathrm{O}$ to estimate the $\delta^{18} \mathrm{O}_{\text {IVF-SW. In }}$ these publications, it is generally assumed that the dominant alkenone producer Emiliania huxleyi and G. ruber have comparable water depth habitats (e.g., Rostek et al., 1993; Emeis et al., 2000; Carter et al., 2008; Sepulcre et al., 2011; Kasper et al., 2014), which is also the case in the subtropical western South Atlantic (Venancio et al., 2017; Ceccopieri et al., 2018). Seasonal corrections over the $\mathrm{U}_{37^{\prime}}^{\mathrm{K}^{\prime}}$ derived SST before application in $\delta^{18} \mathrm{O}_{\mathrm{IVF}-\mathrm{SW}}$ have been considered in regions of extreme seasonal variations in temperature and salinity, as the Mediterranean Sea (e.g., Essallami et al., 2007), which is not the case for the subtropical western South Atlantic.

\section{Results}

As a general result, the same trend was noted for $\delta^{18} \mathrm{O}$, paleotemperature, and relative changes in salinity proxies over the length of cores RJ-1501 and RJ-1502 (Fig. 3a-e). Both records indicate similarity throughout MIS3 and MIS1 intervals. Regarding the slope variations (RJ-1501 $\rightarrow$ RJ-1502), $\delta^{18} \mathrm{O}$ (Fig. 3a) and $\mathrm{U}_{37}^{\mathrm{K}^{\prime}}$-derived SST (Fig. 3c) profiles are in agreement throughout the glacial period until Termination I, when a decoupling occurs, and RJ-1501 data display lower temperature results. From the beginning of MIS 2, a discrepancy between the records indicates a genuine change in behavior by the main environmental conditions. Unlike $\delta^{18} \mathrm{O}$ and $\mathrm{U}_{37}^{\mathrm{K}^{\prime}}$-derived SST profiles, a trend of convergence between the cores' $\delta^{13} \mathrm{C}$ data (Fig. 3b) can be observed in MIS2, particularly during the last deglaciation. The isotopic composition of $G$. ruber ranged from $-0.97 \%$ to $0.72 \%$ o $\left(\delta^{18} \mathrm{O}\right)$ and $0.12 \% \circ$ to $1.65 \% \circ\left(\delta^{13} \mathrm{C}\right)$ in core $\mathrm{RJ}-1501(n=$ $101)$ and from $-0.84 \%$ to $0.95 \% \circ\left(\delta^{18} \mathrm{O}\right)$ and $0.27 \%$ to $1.45 \% \circ\left(\delta^{13} \mathrm{C}\right)$ in core RJ-1502 $(n=72)$. A well-defined decreasing trend of $\delta^{18} \mathrm{O}$ data is observed after the start of the Last Glacial Maximum (LGM) in the core RJ-1501 although less evident in the deeper core RJ-1502 - and is accompanied by an increase in $\delta^{13} \mathrm{C}$ values from $\sim$ ca. 12 to $13 \mathrm{ka}$ in the two cores. The mean $\mathrm{U}_{37^{\prime}}^{\mathrm{K}^{\prime}}$-derived SST was $21.8 \pm 2.5^{\circ} \mathrm{C}(n=77)$ for core RJ-1501 and $20.7 \pm 1.7^{\circ} \mathrm{C}$ $(n=70)$ for core RJ-1502. $\mathrm{U}_{37}^{\mathrm{K}^{\prime}}$-derived SST varied by $8.2^{\circ} \mathrm{C}$ $\left(17.6-25.8^{\circ} \mathrm{C}\right)$ at the location closest to the shelf break and by $8.9^{\circ} \mathrm{C}\left(16.9-25.8^{\circ} \mathrm{C}\right)$ at the slope, with common positive bias located at ca. $39 \mathrm{ka}$ and from ca. $12 \mathrm{ka}$ until recently. Nevertheless, the modern annual SST means are higher $+0.74^{\circ} \mathrm{C}(\mathrm{RJ}-1501)$ and $+1.19^{\circ} \mathrm{C}(\mathrm{RJ}-1502)$ (data from World Ocean Atlas 2013 - WOA13, Locarnini et al., 2013) compared to our Holocene sea surface temperature estimates $\left(\mathrm{RJ}-1501=24.6 \pm 0.88^{\circ} \mathrm{C}\right.$ and RJ-1502 $=24.8 \pm 0.84^{\circ} \mathrm{C}$ ).

The relative changes in the sea surface salinity interval obtained by RJ-1501 and RJ-1502 cores data include the late MIS3 to MIS1. Despite the inconsistency of the $\delta^{18} \mathrm{O}_{\text {IVF-SW }}$ and $\delta \mathrm{D}$-alkenone patterns between ca. 28 and $25 \mathrm{ka}$, both relative changes in salinity parameters display good agreement, and a change in the LGM and last deglaciation separating the local conditions of cores RJ-1501 and RJ-1502 is clearly observed (Fig. 3d, e). The $\delta^{18} \mathrm{O}_{\mathrm{IVF}-\mathrm{SW}}$ records for RJ-1501 and RJ-1502 are presented in Fig. 3d and reveal a millennial-scale variability in the last $50 \mathrm{kyr}$. The mean values of this relative salinity proxy were $1.56( \pm 0.54 \%$; $n=$ $63)$ at site RJ-1501 and $1.25( \pm 0.46 \% ; n=95)$ at RJ-1502. The $\delta \mathrm{D}$-alkenone values at RJ-1501 ranged from $-181 \%$ to $-159 \%$ o $(n=47)$ and between $-185 \%$ and $-153 \%$ at RJ$1502(n=53)$ (Fig. 3e). Decreasing values are observed during the deglaciation and increasing values during the early Holocene, with high values maintained $(\sim 159 \%)$ up to $\sim 5.5 \mathrm{ka}$, with a decreasing trend towards the present (up to ca. $1.7 \mathrm{ka})$.

\section{Discussion}

The synthesis of global SST carried out by the MARGO project inferred that the subtropical gyres in the Atlantic Ocean experienced very modest cooling (ca. $1-2{ }^{\circ} \mathrm{C}$ ) in their center during the LGM (Waelbroeck et al., 2009). G. ruber $\mathrm{Mg} / \mathrm{Ca}$-derived SST estimates from core GL-1090 (24.92 ${ }^{\circ} \mathrm{S}$, $42.51^{\circ} \mathrm{W} ; 2225 \mathrm{~m}$ ) agree with the MARGO compilation and did not indicate prominent cooling during the LGM (Santos et al., 2017a). Assuming a longer timescale, the reported temperatures from core GL-1090 during the LGM verified long-term warming developed since ca. $45 \mathrm{ka}$. According to Santos et al. (2017a), the absence of prominent cooling during the LGM and heat buildup in the region occurred in response to a progressively slower AMOC and glacial climate advance that stored warm waters in the subtropical South Atlantic Gyre, while sea-ice and ice-caps expanded in southern and northern high latitudes.

We compared the $\mathrm{U}_{37}^{\mathrm{K}^{\prime}}$-derived SST from cores RJ-1501 and RJ-1502 to the late-glacial context proposed by Santos et al. (2017a) through core GL-1090. Figure 4a and b show that $\mathrm{U}_{37}^{\mathrm{K}^{\prime}}$-derived SST was consistently colder than the $\mathrm{Mg} / \mathrm{Ca}$ derived SST throughout the last ca. $50 \mathrm{kyr}$ in the area. Despite the obvious deviations in terms of absolute temperature reconstruction that different ecology and calibration prox- 


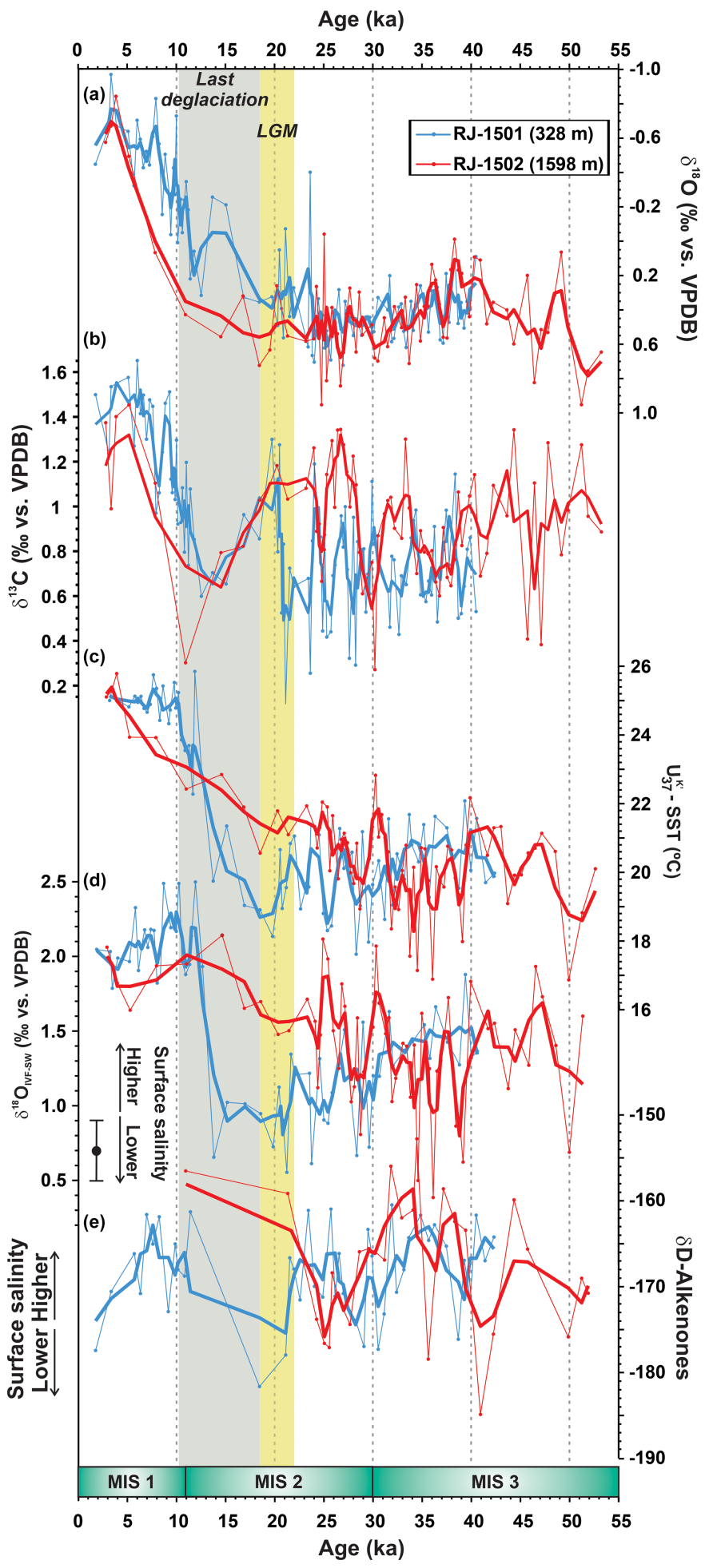

Figure 3. Organic and inorganic proxies developed from marine sediment cores RJ-1501 (blue) and RJ-1502 (red). (a) Oxygen isotope $\left(\delta^{18} \mathrm{O}\right)$ of the planktic foraminifera G. ruber. (b) Carbon isotope $\left(\delta^{13} \mathrm{C}\right)$ of planktic foraminifera $G$. ruber. (c) Alkenone $\left(\mathrm{U}_{37}^{\mathrm{K}^{\prime}}\right)$-derived sea surface temperature (SST). (d) Ice-volume free seawater oxygen isotope $\left(\delta^{18} \mathrm{O}_{\mathrm{IVF}-\mathrm{SW}}\right)$ derived from the $\delta^{18} \mathrm{O}$ composition of G. ruber and $\mathrm{U}_{37}^{\mathrm{K}^{\prime}}$-derived SST. (e) $\delta \mathrm{D}$-Alkenones. Records are depicted by the original data (dots and thin line) and the respective three-point running average (thick line). Yellow and grey bars denote the Last Glacial Maximum (LGM) and last deglaciation, respectively. The vertical bar at the left of panel (d) indicates the total uncertainty associated with the $\delta^{18} \mathrm{O}_{\mathrm{IVF}}-\mathrm{SW}$. Marine isotope stages (MIS) are indicated at the bottom of the panel. 
ies will display, it is possible to address a similar pattern that emerges between the most offshore RJ-1502 and GL1090. Both cores recorded progressive temperature increases since the late-glacial towards the Holocene, without significant cooling during the LGM (Fig. 4a). This indicates that alkenones and surface-dwelling $G$. ruber were influenced by the BC core, which carried warm waters retained in the South Atlantic Subtropical Gyre to the Santos Basin during the end of the last glacial cycle. Interestingly, $\mathrm{U}_{37}^{\mathrm{K}^{\prime}}$-derived SST from RJ-1501 followed an opposite trajectory to that indicated by RJ-1502 and GL-1090 (Fig. 4b), where RJ-1501 presented a gradual surface cooling towards the LGM with accentuated warming only after ca. $18.5 \mathrm{ka}$, despite being separated by only $40 \mathrm{~km}$ from RJ-1502. The relative changes in ocean salinity indicated by $\delta^{18} \mathrm{O}_{\mathrm{IVF}-\mathrm{SW}}$ agree with the patterns indicated by the SST reconstructions; i.e., RJ-1502 and GL1090 cores displayed progressive ocean surface salinification from the late-glacial period to the Holocene (Fig. 4c), while RJ-1501 presented surface freshening, achieving its maximum during the LGM and early deglaciation (Fig. 4d). The reconstructed core RJ-1501 parameters were only similar to those from RJ-1502 and GL-1090 during the Holocene (Fig. 4). This is strong evidence that the planktic organisms accumulated in RJ-1501 core were under the influence of another oceanographic regime during the last glacial cycle.

One could argue that RJ-1501 presented a divergent evolution due to the influence of wind-driven, shelf-break SACW upwelling. Although $\mathrm{U}_{37}^{\mathrm{K}^{\prime}}$-derived SST has cooled continuously toward the LGM, temperatures were still warmer than those commonly reported for the occurrence of SACW shoaling (ca. $16^{\circ} \mathrm{C}$ ) (Belem et al., 2013). Through the relative abundance of certain planktic foraminifera species, Lessa et al. (2017) proposed that upwelling in this region from the LGM to the Holocene was rather retracted because the glacial wind-regime (weak NE winds) did not favor the pumping of cold and nutrient-rich central waters to the photic zone. Portilho-Ramos et al. (2019) also considered a higher glacial productivity during earlier intervals of the last glacial (e.g., MIS 3), and from the LGM toward the Holocene the conditions for such productivity declined. Under this scenario, it could be considered that the Cabo Frio upwelling system was already confined to its modern position in inner parts of the continental shelf and far from core RJ-1501. Figure 3b exhibits the planktic G. ruber $\delta^{13} \mathrm{C}$ composition of cores RJ-1501 and RJ-1502. Several factors are recognized to influence the carbon isotope composition of planktic foraminifera, such as metabolic vital effects, the presence of symbiont bearing, the ocean carbonate chemistry, and global distribution of ${ }^{13} \mathrm{C}$-depleted carbon between marine and terrestrial reservoirs (e.g., Bijma et al., 1998; Bijma, 2002; Spero et al., 1997; Oliver et al., 2010). The G. ruber $\delta^{13} \mathrm{C}$ reconstruction shows that RJ-1501 was slightly more depleted than RJ-1502 prior to $\sim 22 \mathrm{ka}$, but from the LGM/last deglaciation interval both records present a very similar evolution with a pronounced decline during the last deglaciation that has been suggested as a global imprint caused by the airsea exchange (Lynch-Stieglitz et al., 2019). If the RJ-1501 site were under the influence of strong upwelling of SACW during LGM and last deglaciation, it would be expected that the $G$. ruber $\delta^{13} \mathrm{C}$ of RJ-1501 would have shown a shift from the $G$. ruber $\delta^{13} \mathrm{C}$ of RJ-1502, at least in part, because of the influence of nutrient-enriched SACW compared to the nutrient-depleted surface Tropical Water (Kroopnick, 1985; Venancio et al., 2014). However, the good agreement of both G. ruber $\delta^{13} \mathrm{C}$ during the LGM and last deglaciation indicates that it is unlikely that cold and nutrient-rich tongues of SACW accounted for the surface water patterns seen in RJ1501.

Once this alternative explanation is disregarded, it is remarkable that the temperature evolution of core RJ-1501 (with warming only after $18.5 \mathrm{ka}$ ) resembles the deglacial pattern inferred from mid- to high-latitude records for the Southern Hemisphere. $\mathrm{U}_{37}^{\mathrm{K}^{\prime}}$-derived SST from ODP Site 1233 and MD07-3128 (off southern Chile) presented deglacial warming initiated shortly after $19 \mathrm{ka}$ (Fig. 5a, b). Such warming was a combined response of the temperature increase around Antarctica due to the bipolar seesaw during the Heinrich stadial 1 interval and the accentuated release of $\mathrm{CO}_{2}$ from the deep ocean towards the atmosphere (Lamy et al., 2007; Caniupán et al., 2011) (Fig. 5d, e). Mg/Caderived SST from core TNO57-21 (SE South Atlantic) indicated deglacial warming from ca. $18.5 \mathrm{ka}$, also in response to the pattern imposed by the bipolar seesaw mechanism (Barker et al., 2009). The mean air temperature reconstructed through lipids glycerol dialkyl glycerol tetraethers (GDGTs) from core GeoB6211-2 (SE Brazilian coast) displayed significant warming slightly after the records above (ca. $16.5 \mathrm{ka}$ ) but still within the main warming interval in Antarctica (Chiessi et al., 2015) (Fig. 5c). A glaciolacustrine varved record (FCMC17) that reports the dynamics of ice-margin retreat of the Patagonian Ice Sheet indicates that the varve thickness decreases in two steps after the LGM, denouncing a prominent regional warming between 18 and $17.4 \mathrm{ka}$ (Bendle et al., 2019). According to these authors, this glacial retreat highlights the potential synchronicity in atmospheric warming trends over the Southern Hemisphere mid- to high latitudes with the onset of the last deglaciation. Part of the warming responsible for the Patagonian Ice Sheet melting recorded from $18 \mathrm{ka}$ would be the result of unbalanced oceanic heat distribution due to the bipolar seesaw resulting in increasing temperatures in the South Atlantic, the South Pacific, and Antarctica, with subsequent upwelling-driven $\mathrm{CO}_{2}$ release from the Southern Ocean (EPICA community members, 2004; Lamy et al., 2007; Lüthi et al., 2008; Barker et al., 2009; Bendle et al., 2019) (Fig. 5a-e). In relative disagreement with this pattern is the $\mathrm{U}_{37}^{\mathrm{K}^{\prime}}$-derived SST from core GC528, located in the southern flank of the Falklands (Malvinas) Plateau (Roberts et al., 2017). This core records, similarly to GL-1090, relatively warm SST during the LGM, but this pattern was followed by a persistent cold interval 

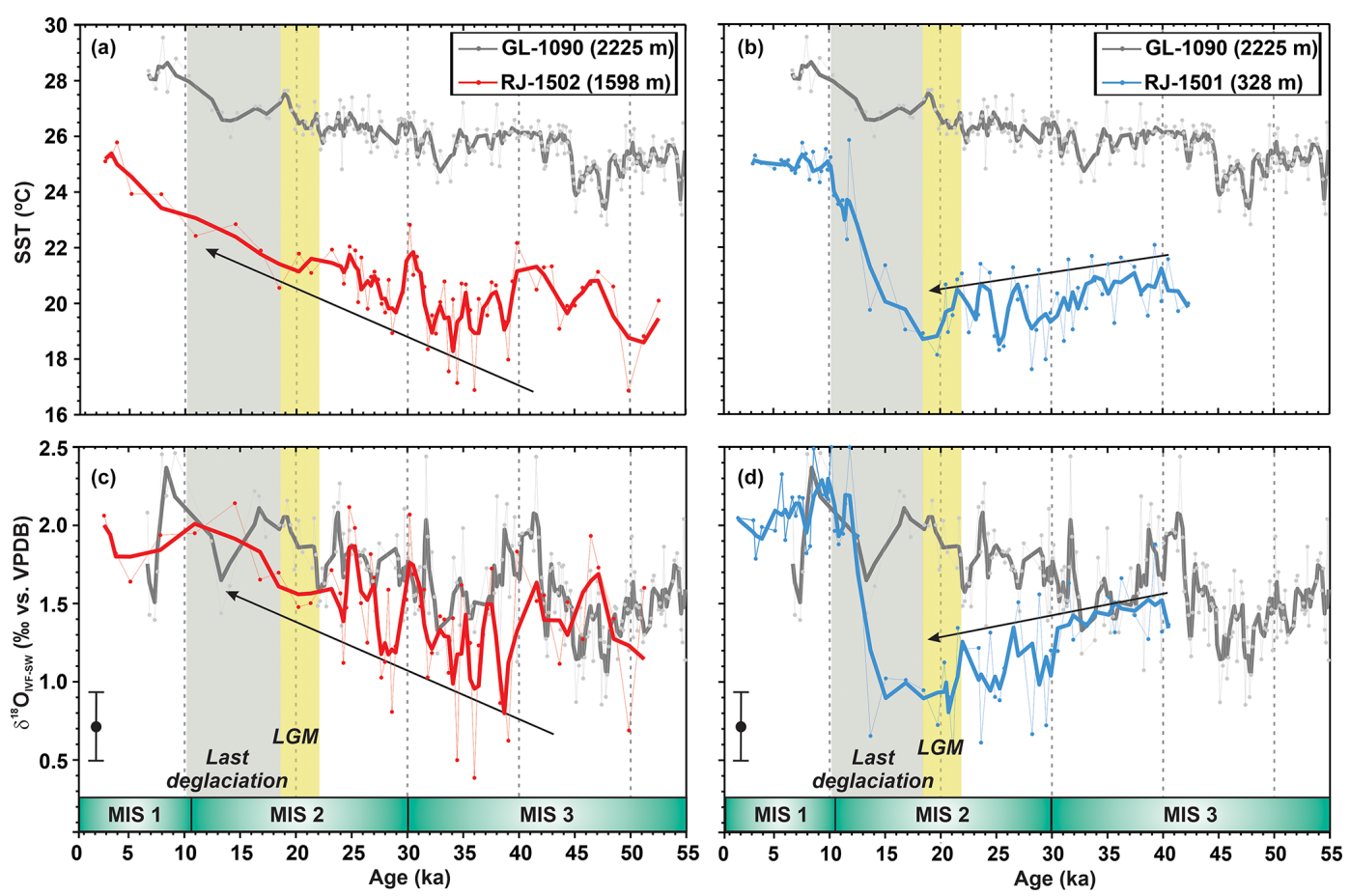

Figure 4. Comparison of the records from marine sediment cores RJ-1501 (blue), RJ-1502 (red) (this study), and GL-1090 (grey) (Santos et al., 2017a). (a, b) Alkenone ( $\mathrm{U}_{37}^{\mathrm{K}^{\prime}}$ )-derived sea surface temperature (SST) from cores RJ-1502 and RJ-1501 and Mg/Ca-derived SST from core GL-1090. (c, d) Ice-volume free seawater oxygen isotope $\left(\delta^{18} \mathrm{O}_{\mathrm{IVF}-\mathrm{SW}}\right)$ from cores RJ-1502, RJ-1501, and GL-1090. Records are depicted by the original data (dots and thin line) and the respective three-point running average (thick line). Yellow and grey bars denote the Last Glacial Maximum (LGM) and last deglaciation, respectively. The vertical bars at the left of panels (c) and (d) indicate the total uncertainty associated with the $\delta^{18} \mathrm{O}_{\mathrm{IVF}-\mathrm{SW}}$. Marine isotope stages (MIS) are indicated at the bottom of the panel.

interrupted only very late (ca. $12 \mathrm{ka}$ ) in the last deglaciation. The authors argued that a weakening of the "cold water route" would prevent the transport of Pacific cold waters to the GC528 site during the LGM. Eventually, a small portion of this connection was still active during the LGM, transporting such Pacific cold waters very proximal to the South American margin reaching the area where Subantarctic Shelf Water is formed. However, the absence of warming during early deglaciation is more challenging to fit into this perspective. Despite this, most of the studies suggest that large areas of the northern portion of the Subtropical Front warmed during the early last deglaciation after the LGM cooling relatively synchronous to Antarctica. It is reasonable to assume that the Malvinas Current, sourced from the northern limb of the Antarctic Circumpolar Current, could have transported this pattern northward, influencing Subantarctic Shelf Water formation. This temperature evolution characterized by a cold LGM and early-deglacial warming can be traced in lower latitudes along the SE Brazilian coast due to the northward-flowing BCC (Fig. 5a-e). Apart from the impact of the BCC, cores RJ-1502 and GL-1090 (Santos et al., 2017a) did not record this mid- to high Southern Hemisphere pattern (Fig. 4a, b).
A recent investigation applying a dinocyst assemblage (core GeoB3202-1, $1090 \mathrm{~m}$ water depth) in a region near cores RJ-1501, RJ-1502, and GL-1090 also suggests the occurrence of cold SST during the LGM (Gu et al., 2019). These authors explain the discrepancy between their results and those reported by GL-1090 (Santos et al., 2017a) by invoking shifts in the modern wind-driven upwelling area. Instead, we reason that such conflict could be reconciled by simply considering that shallower cores (RJ-1501, this study, and GeoB3202-1, Gu et al., 2019) have a much higher chance of being within the BCC influence zone than deeper records (RJ-1502, this study, and GL-1090, Santos et al., 2017a).

During the late-glacial period and Heinrich stadial 1 interval, it is very well documented that large areas in adjacent South America experienced wetter conditions due to a noticeable strengthening of the precipitation associated with the South American Monsoon System (SAMS) (Cruz et al., 2005; Stríkis et al., 2015, 2018; Novello et al., 2017; $\mathrm{Gu}$ et al., 2018). The increased precipitation volume would be drained by the Paraná Basin and subsequently discharged into the ocean by La Plata River, mixing a continental freshwater influence with Subantarctic Shelf waters, similar to what occurs today (Burone et al., 2013). In this context, BCC waters would carry not only a temperature pattern linked to 


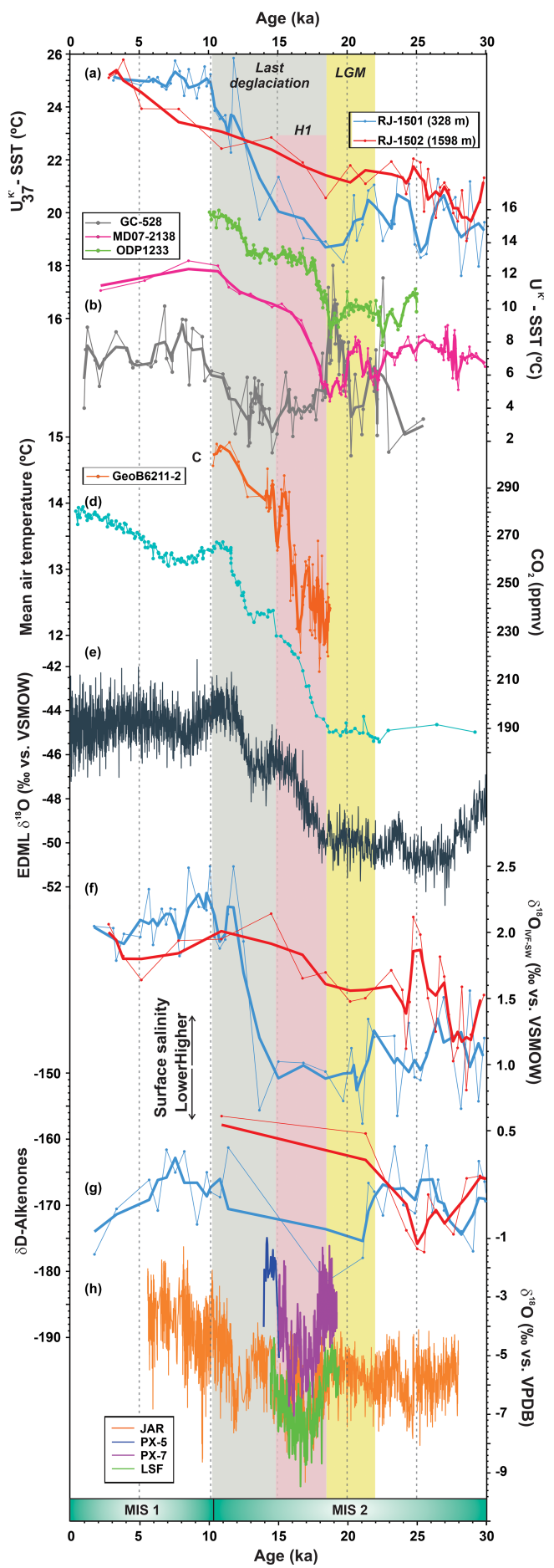

Figure 5. Comparison of the marine sediment cores RJ-1501 (blue) and RJ-1502 (red) with other Southern Hemisphere records. (a) Alkenone $\left(\mathrm{U}_{37}^{\mathrm{K}^{\prime}}\right.$ )-derived sea surface temperature (SST) from cores RJ-1502 and RJ-1501. (b) $\mathrm{U}_{37}^{\mathrm{K}^{\prime}}$-derived SST from ODP Site 1233 (green; Lamy et al., 2007), MD07-2138 (purple; Caniupán et al., 2011), and GC528 (grey; Roberts et al., 2017). (c) Mean air temperature from GeoB62112 (Chiessi et al., 2015). (d) Carbon dioxide $\left(\mathrm{CO}_{2}\right)$ concentration from Antarctic EPICA Dome C (Lüthi et al., 2008) on the Antarctic Ice Core Chronology (AICC2012) (Veres et al., 2013; Bazin et al., 2013). (e) Antarctic oxygen isotope from EDML (EPICA community members, 2004) on the AICC2012 chronology. (f) Ice-volume free seawater oxygen isotope ( $\left.\delta^{18} \mathrm{O}_{\mathrm{IVF}} \mathrm{SW}\right)$ from RJ-1501 and RJ-1502. (g) $\delta$ D-Alkenones from RJ-1501 and RJ-1502. (h) Speleothem oxygen isotope from Jaraguá cave (JAR) (Novello et al., 2017) and Paixão (PX-5 and PX-7) and Lapa Sem Fim (LSF) caves (Stríkis et al., 2015). Records are depicted by the original data (dots and thin line) and the respective three-point running average (thick line). Yellow, red, and grey bars denote the Last Glacial Maximum (LGM), Heinrich stadial 1, and last deglaciation, respectively. Marine isotope stages (MIS) are indicated at the bottom of the panel. 
the thermal evolution of the mid- to high latitudes of the Southern Hemisphere but also a sign of low salinity due to higher rainfall throughout the continent. The notion of a fresher surface over the shelf-break area is demonstrated by the $\delta^{18} \mathrm{O}_{\mathrm{IVF}-\mathrm{SW}}$ and $\delta \mathrm{D}$ of RJ-1501 core, which became progressively lower throughout the late-glacial interval, producing a clear density contrast with the more saline offshore waters (Fig. 5f, g). Hence, a stronger BCC influence would explain the residence of colder and fresher surface waters over the RJ-1501 site (and other relatively shallow cores, e.g., Gu et al., 2019) but not in cores collected deeper from the continental slope. It is relevant to highlight that G. ruber $\delta^{18} \mathrm{O}$ of RJ-1501 and RJ-1502 do not show significant differences throughout the studied period, except for the offset occurred in RJ-1501 to more negative values during the last deglaciation. This means that most of the $\delta^{18} \mathrm{O}_{\text {IVF-SW }}$ variability is being controlled by the $\mathrm{U}_{37^{\prime}}^{\mathrm{K}^{\prime}}$-derived SST. Considering that in our interpretation, the $\mathrm{U}_{37}^{\mathrm{K}^{\prime}}$-derived SST of $\mathrm{RJ}-1501$ is sourced from southern areas of the continental shelf, the more substantial influence of the SST upon the $\delta^{18} \mathrm{O}_{\mathrm{IVF}-\mathrm{SW}}$ constitutes additional evidence to assume that RJ-1501 recorded a signal from higher latitudes of the western South Atlantic instead of that carried within the Tropical Water.

In order to better demonstrate the contrast between the individual cores during the end of the last glacial cycle, we transferred the RJ-1501 age model to RJ-1502 and subtracted the average around zero (RJ-1502 minus RJ-1501) of $\mathrm{U}_{37^{-}}^{\mathrm{K}^{\prime}}$ derived SST and $\delta^{18} \mathrm{O}_{\mathrm{IVF}-\mathrm{SW}}$ (i.e., $\Delta \mathrm{U}_{37^{\mathrm{K}^{\prime}}}$-derived SST and $\Delta \delta^{18} \mathrm{O}_{\text {IVF-SW }}$ ) (Fig. 6). The records were bootstrapped, and 2.5th and 97.5th percentiles are also presented (Fig. 6). This exercise demonstrates that a sharp SST gradient (reaching $>3{ }^{\circ} \mathrm{C}$ in its superior band) was formed toward the LGM and early deglaciation, with a maximum between ca. 20 and $15 \mathrm{ka}$ (Fig. 6a). This gradient indicates that the $\mathrm{BC}$ offshore waters over the RJ- 1502 site were ca. $2{ }^{\circ} \mathrm{C}$ warmer than the inner waters over the RJ-1501 site, which is the double that of the annual SST gradient observed today in the region. In the case of the $\Delta \delta^{18} \mathrm{O}_{\mathrm{IVF}-\mathrm{SW}}$, the difference achieves ca. $0.8 \%$ in the same period, corresponding to approximately a 1.5 salinity unit difference considering the seawater $\delta^{18} \mathrm{O}$-salinity relationship for the region (Belem et al., 2019).

In regions where steep oceanic fronts develop, like the Southern Benguela where strong intrusions of warm Agulhas Current water occur (Hardman-Mountford et al., 2003), the air-sea interaction works on a small scale and creates physical mechanisms of atmospheric response to temperature gradients of the sea surface that are reflected mainly over the wind stress and moisture anomalies (Saravanan and Chang, 2019). The across-shelf SST gradient caused by the shearing between the $\mathrm{BC}$ and $\mathrm{BCC}$ is reported modulating the marine atmospheric boundary layer in the southern Brazilian continental shelf (Mendonça et al., 2017). The atmospheric turbulence caused by heat fluxes from the warm side of the
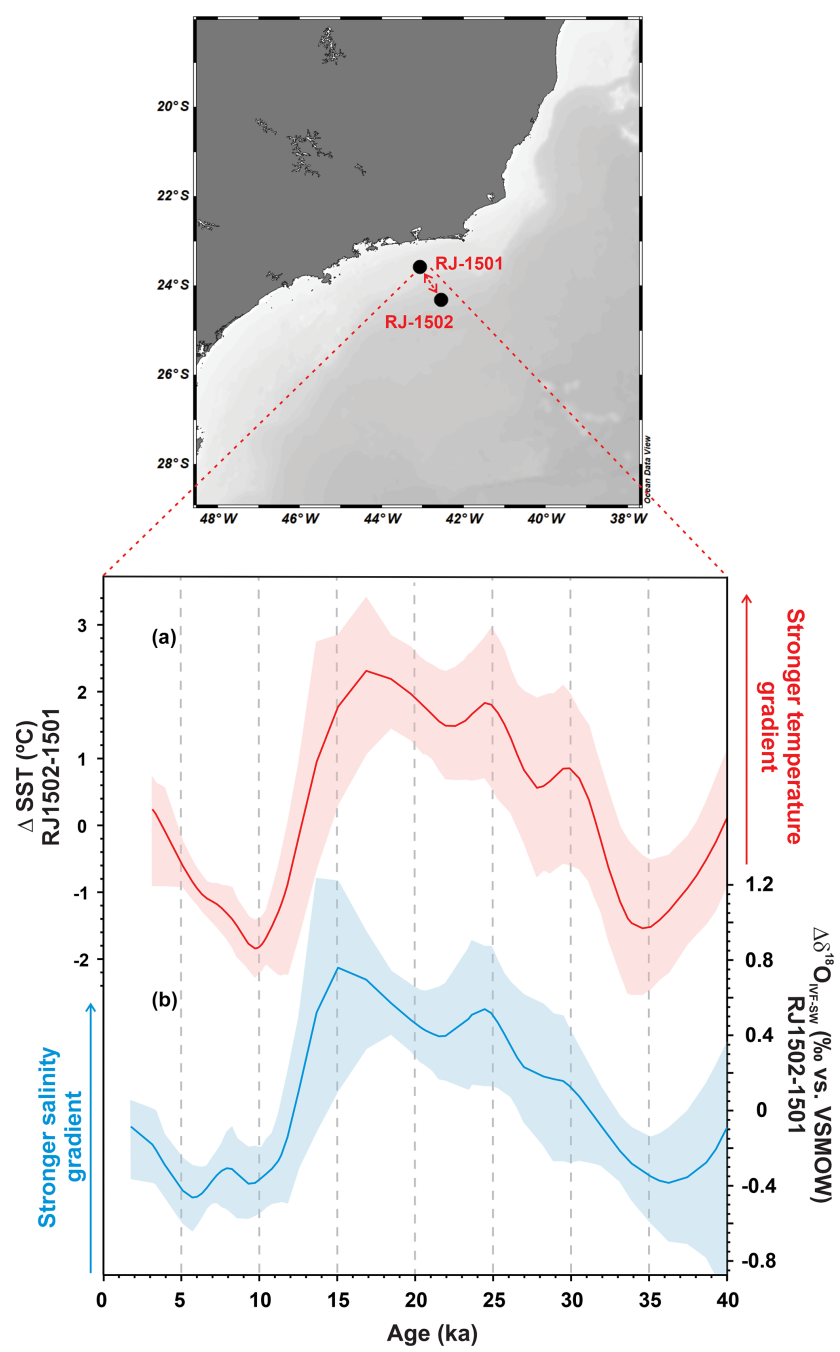

Figure 6. Sea surface temperature and salinity gradient formed in the area between the marine sediment cores RJ-1501 and RJ-1502 (map in the uppermost panel) during the Last Glacial Maximum and early deglaciation interval. Records were placed on a common timescale (RJ-1501), and the means around zero were subtracted (RJ-1502 minus RJ-1501) to produce alkenone $\left(\mathrm{U}_{37}^{\mathrm{K}^{\prime}}\right)$-derived sea surface temperature (SST) and $\Delta \delta$-ice-volume free seawater oxygen isotope $\left(\Delta \delta^{18} \mathrm{O}_{\mathrm{IVF}-\mathrm{SW}}\right)$. The records were bootstrapped using the Acycle software with a $10 \%$ window (Li et al., 2019) and presented with the 2.5th and 97.5th percentiles (red and blue shaded areas). (a) $\Delta \delta \mathrm{U}_{37}^{\mathrm{K}^{\prime}}$-derived SST. (b) $\Delta \delta^{18} \mathrm{O}_{\mathrm{IVF}-\mathrm{SW}}$.

ocean gradient has been investigated as an important factor influencing the weather of coastal regions off southern Brazil (de Camargo et al., 2013; Pezzi et al., 2016). Enhanced SST gradient is suggested as a factor that stimulates air-sea moisture exchange, which fuels annual coastal precipitation along with southern areas of the continental shelf (Reboita et al., 2010; Tirabassi et al., 2015). In a scenario of stronger northward spreading of BCC waters, like the one experienced during the LGM/early deglaciation, the impacts over 
regional precipitation could extend to lower latitudes of the area. Therefore, our results demonstrate that the background conditions during the end of the last glacial cycle with a disturbed AMOC, reduced equatorial heat export, and enhanced SAMS (leading to an increase in La Plata river discharge) created conditions to accentuate the hydrographical contrast between the $\mathrm{BC}$ and $\mathrm{BCC}$. Considering the future projections of AMOC weakening (Liu et al., 2017) and sea-level rising, the gradient strengthening reported herein may be a likely prospect for the southern Brazilian continental shelf.

\section{Conclusions}

In this study, we reconstructed the SST and $\delta^{18} \mathrm{O}_{\mathrm{IVF}-\mathrm{SW}}$ through organic and inorganic geochemical proxies from two sediment cores collected from the upper (RJ-1501) and lower (RJ-1502) continental slope of the subtropical western South Atlantic. Although only $40 \mathrm{~km}$ apart, these records show considerably distinct hydrographic conditions throughout the end of the last glacial cycle. These contrasting results were reconciled assuming that the shallower and closer to the continent core RJ-1501 was under the influence of cold and fresh waters carried by the BCC, while the deeper and more offshore RJ-1502 was under the influence of the warm and saltier BC. A comparison with other records collected in the $\mathrm{BC}$ area supports this interpretation. Our results suggest that the conditions experienced during the last glacial transition, i.e., a weak AMOC and strong SAMS, increased the temperature and salinity gradient between the $\mathrm{BC}$ and $\mathrm{BCC}$. Depending on the state of AMOC, this scenario may be accentuated in the coming decades.

Data availability. Data of this study are available upon request to Letícia Luz (leticiagluz@gmail.com).

Author contributions. LGL, TIE, and RSC contributed to the study conception and design; LGL and TPS performed the age model calculation; LGL, TPS, and RSC wrote the first draft of the paper; LGL, DM, BA, NH, SMS, and RHN executed chemical analysis and/or contributed with sample preparation. All authors contributed to paper revision and read and approved the submitted version.

Competing interests. The authors declare that they have no conflict of interest.

Acknowledgements. We thank Seaseep ${ }^{\circledR}$ and R/V Inspector II staff for sampling help. We also thank all members of Laboratory for Ion Beam Physics at ETH Zurich for facilitating the ${ }^{14} \mathrm{C}$ measurements. We also thank the editor, Erin McClymont, and two anonymous reviewers who significantly contributed to improve the paper.
Financial support. This research has been supported in part by the Coordenação de Aperfeiçoamento de Pessoal de Nível Superior - Brasil (CAPES) (finance code 001) and by FAPERJ (process no. E-26/203.066/2017). Leticia Luz has been supported by the CAPES for a doctorate (proc. no. 88881.151666/2017-00) and a PDSE (proc. no. 88881.134411/2016-01) scholarship. Renato S. Carreira has been supported by a research fellowship from $\mathrm{CNPq}$ (grant no. 309347/2017-3).

Review statement. This paper was edited by Erin McClymont and reviewed by two anonymous referees.

\section{References}

Albuquerque, A. L., Meyers, P., Belem, A. L., Turcq, B., Siffedine, A., Mendoza, U., and Capilla, R.: Mineral and elemental indicators of post-glacial changes in sediment delivery and deposition under a western boundary upwelling system (Cabo Frio, southeastern Brazil), Palaeogeogr. Palaeocl., 445, 72-82, https://doi.org/10.1016/j.palaeo.2016.01.006, 2016.

Arz, H. W., Pätzold, J., and Wefer, G.: The deglacial history of the western tropical Atlantic as inferred from high resolution stable isotope records off northeastern Brazil, Earth Planet. Sc. Lett., 167, 105-117, https://doi.org/10.1016/S0012-821X(99)00025-4, 1999.

Arz, H. W., Gerhardt, S., Pätzold, J., and Röhl, U.: Millennial-scale changes of surface- and deep-water flow in the western tropical Atlantic linked to Northern Hemisphere high-latitude climate during the Holocene, Geology, 29, 239-242, https://doi.org/10.1130/00917613(2001)029<0239:MSCOSA>2.0.CO;2, 2001.

Ballalai, J. M., Santos, T. P., Lessa, D. O., Venancio, I. M., Chiessi, C. M., Johnstone, H. J. H., Kuhnert, H., Claudio, M. R., Toledo, F., Costa, K. B., and Albuquerque, A. L. S.: Tracking spread of the Agulhas Leakage into the western South Atlantic and its northward transmission during the Last Interglacial,Paleoceanography and Paleoclimatology, 34, 1744-1760, https://doi.org/10.1029/2019PA003653, 2019.

Barker, S., Diz, P., Vautravers, M. J., Pike, J., Knorr, G., Hall, I. R., and Broecker, W. S.: Interhemispheric Atlantic seesaw response during the last deglaciation, Nature, 457, 1097-1102, https://doi.org/10.1038/nature07770, 2009.

Bazin, L., Landais, A., Lemieux-Dudon, B., Toyé Mahamadou Kele, H., Veres, D., Parrenin, F., Martinerie, P., Ritz, C., Capron, E., Lipenkov, V., Loutre, M.-F., Raynaud, D., Vinther, B., Svensson, A., Rasmussen, S. O., Severi, M., Blunier, T., Leuenberger, M., Fischer, H., Masson-Delmotte, V., Chappellaz, J., and Wolff, E.: An optimized multi-proxy, multi-site Antarctic ice and gas orbital chronology (AICC2012): 120-800 ka, Clim. Past, 9, 17151731, https://doi.org/10.5194/cp-9-1715-2013, 2013.

Behling, H., Arz, H. W., and Wefer, G.: Late Quaternary vegetational and climate dynamics in northeastern Brazil, inferences from marine core GeoB 3104-1, Quaternaty Sci. Rev., 19, 981994, 2000.

Belem, A. L., Castelao, R. M., and Albuquerque, A. L.: Controls of subsurface temperature variability in a western bound- 
ary upwelling system, Geophys. Res. Lett., 40, 1362-1366, https://doi.org/10.1002/grl.50297, 2013.

Belem, A. L., Caricchio, C., Albuquerque, A. L. S., Venancio, I. M., Zucchi, M. D. R., Santos, T. H. R., and Alvarez, Y. G.: Salinity and stable oxygen isotope relationship in the Southwestern Atlantic: constraints to paleoclimate reconstructions, An. Acad. Bras. Cienc., 91, e20180226, https://doi.org/10.1590/0001-3765201920180226, 2019.

Bendle, J. M., Palmer, A. P., Thorndycraft, V. R., and Matthews, I. P.: Phased Patagonian Ice Sheet response to Southern Hemisphere atmospheric and oceanic warming between 18 and $17 \mathrm{ka}$, Scientific Reports, 9, 4133, https://doi.org/10.1038/s41598-01939750-w, 2019.

Bijma, J.: Impact of the ocean carbonate chemistry on living foraminiferal shell weight: Comment on "Carbonate ion concentration in glacial-age deep waters of the Caribbean Sea" by W. S. Broecker and E. Clark, Geochem. Geophy. Geosy., 3, 1064, https://doi.org/10.1029/2002GC000388, 2002.

Bijma, J., Hemleben, C., Huber, B. T., Erlenkeuser, H., and Kroon, D.: Experimental determination of the ontogenetic stable isotope variability in two morphotypes of Globigerinella siphonifera (d'Orbigny), Mar. Micropaleontol., 35, 141-160, https://doi.org/10.1016/S0377-8398(98)00017-6, 1998.

Blaauw, M. and Christeny, J. A.: Flexible paleoclimate age-depth models using an autoregressive gamma process, Bayesian Anal., 6, 457-474, https://doi.org/10.1214/11-BA618, 2011.

Bouimetarhan, I., Chiessi, C. M., González-Arango, C., Dupont, L., Voigt, I., Prange, M., and Zonneveld, K.: Intermittent development of forest corridors in northeastern Brazil during the last deglaciation: Climatic and ecologic evidence, Quaternary Sci. Rev., 192, 86-96, https://doi.org/10.1016/j.quascirev.2018.05.026, 2018.

Burckel, P., Waelbroeck, C., Gherardi, J. M., Pichat, S., Arz, H., Lippold, J., Dokken, T., and Thil, F.: Atlantic Ocean circulation changes preceded millennial tropical South America rainfall events during the last glacial, Geophys. Res. Lett., 42, 411-418, https://doi.org/10.1002/2014GL062512, 2015.

Burone, L., Ortega, L., Franco-Fraguas, P., Mahiques, M., GarcíaRodriguez, F., Venturini, N., Marin, Y., Brugnoli, E., Nagai, R., Muniz, P., Bícego, M., Figueira, R., and Salaroli, A.: A multiproxy study between the Río de la Plata and the adjacent South-western Atlantic inner shelf to assess the sediment footprint of river vs. marineinfluence, Cont. Shelf Res., 55, 141-154, https://doi.org/10.1016/j.csr.2013.01.003, 2013.

Campos, E. J. D., Lorenzzetti, J. A., Stevenson, M. R., Stech, J. L., and de Souza, R. B.: Penetration of waters from the BrazilMalvinas confluence region along the south american continental shelf up to $23^{\circ} \mathrm{S}$, An. Acad. Bras. Cienc., 68, 49-58, 1996.

Caniupán, M., Lamy, F., Lange, C. B., Kaiser, J., Arz, H., Kilian, R., Baeza Urrea, O., Aracena, C., Hebbeln, D., Kissel, C., Laj, C., Mollenhauer, G., and Tiedemann, R.: Millennial-scale sea surface temperature and Patagonian Ice Sheet changes off southernmost Chile $\left(53^{\circ} \mathrm{S}\right)$ over the past $\sim 60 \mathrm{kyr}$, Paleoceanography, 26 , PA3221, https://doi.org/10.1029/2010PA002049, 2011.

Cao, Y., Liu, W., Sauer, P. E., Wang, Z., and Li, Z.: An evaluation of alumina reaction tube conditioning for high-precision ${ }^{2} \mathrm{H} /{ }^{1} \mathrm{H}$ isotope measurements via gas chromatography/thermal conversion/isotope ratio mass spectrometry, Rapid Commun. Mass Sp., 26, 2577-2583, https://doi.org/10.1002/rcm.6378, 2012.
Carter, L., Manighetti, B., Ganssen, G., and Northcote, L.: Southwest Pacific modulation of abrupt climate change during the Antarctic Cold Reversal-Younger Dryas, Palaeogeogr. Palaeocl., 260, 284-298, https://doi.org/10.1016/j.palaeo.2007.08.013, 2008.

Ceccopieri, M., Carreira, R. S., Wagener, A. L. R., Hefter, J. H., and Mollenhauer, G.: On the application of alkenoneand GDGT-based temperature proxies in the south-eastern Brazilian continental margin, Org. Geochem., 126, 43-56, https://doi.org/10.1016/j.orggeochem.2018.10.009, 2018.

Chiessi, C. M., Mulitza, S., Paul, A., Pätzold, J., Groeneveld, J., and Wefer, G.: South Atlantic interocean exchange as the trigger for the Bøolling warm event, Geology, 36, 919-922, https://doi.org/10.1130/G24979A.1, 2008.

Chiessi, C. M., Mulitza, S., Mollenhauer, G., Silva, J. B., Groeneveld, J., and Prange, M.: Thermal evolution of the western South Atlantic and the adjacent continent during Termination 1, Clim. Past, 11, 915-929, https://doi.org/10.5194/cp-11915-2015, 2015.

Crivellari, S., Chiessi, C. M., Kuhnert, H., Häggi, C., Mollenhauer, G., Hefter, J., Portilho-Ramos, R., Schefuß, E., and Mulitza, S.: Thermal response of the western tropical Atlantic to slowdown of the Atlantic Meridional Overturning Circulation, Earth Planet. Sc. Lett., 519, 120-129, https://doi.org/10.1016/j.epsl.2019.05.006, 2019.

Cruz, F. W., Burns, S. J., Karmann, I., Sharp, W. D., Vuille, M., Cardoso, A. O., Ferrari, J. A., Silva Dias, P. L., and Viana, O.: Insolation-driven changes in atmospheric circulation over the past 116,000 years in subtropical Brazil, Nature, 434, 63-66, https://doi.org/10.1038/nature03365, 2005.

de Camargo, R., Todesco, E., Pezzi, L. P., and de Souza, R. B.: Modulation mechanisms of marine atmospheric boundary layer at the Brazil-Malvinas Confluence region, J. Geophys. Res.-Atmos., 118, 6266-6280, https://doi.org/10.1002/jgrd.50492, 2013.

de Souza, R. B. and Robinson, I. S.: Lagrangian and satellite observations of the Brazilian Coastal Current, Cont. Shelf Res., 24, 241-262, https://doi.org/10.1016/j.csr.2003.10.001, 2004.

Emeis, K.-C., Struck, U., Schulz, H.-M., Rosenberg, R., Bernasconi, S., Erlenkeuser, H., Sakamoto, T., and MartinezRuiz, F.: Temperature and salinity variations of Mediterranean Sea surface waters over the last 16,000 years from records of planktonic stable oxygen isotopes and alkenone unsaturation ratios, Palaeogeogr. Palaeocl., 158, 259-280, https://doi.org/10.1016/S0031-0182(00)00053-5, 2000.

EPICA community members: Eight glacial cycles from an Antarctic ice core, Nature, 429, 623-628, https://doi.org/10.1038/nature02599, 2004.

Essallami, L., Sicre, M. A., Kallel, N., Labeyrie, L., and Siani, G.: Hydrological changes in the Mediterranean Sea over the last 30,000 years, Geochemistry, Geophys. Geosystems, 8, Q07002, https://doi.org/10.1029/2007GC001587, 2007.

Govin, A., Chiessi, C. M., Zabel, M., Sawakuchi, A. O., Heslop, D., Hörner, T., Zhang, Y., and Mulitza, S.: Terrigenous input off northern South America driven by changes in Amazonian climate and the North Brazil Current retroflection during the last $250 \mathrm{ka}$, Clim. Past, 10, 843-862, https://doi.org/10.5194/cp-10843-2014, 2014.

Grant, K. M., Rohling, E. J., Bar-Matthews, M., Ayalon, A., Medina-Elizalde, M., Ramsey, C. B., Satow, C., and Roberts, 
A. P.: Rapid coupling between ice volume and polar temperature over the past 150,000 years, Nature, 491, 744-747, https://doi.org/10.1038/nature11593, 2012.

Gu, F., Zonneveld, K. A. F., Chiessi, C. M., Arz, H. W., Pätzold, J., and Behling, H.: Long-term vegetation, climate and ocean dynamics inferred from a 73,500 years old marine sediment core (GeoB2107-3) off southern Brazil, Quaternary Sci. Rev., 172, 55-71, https://doi.org/10.1016/j.quascirev.2017.06.028, 2017.

Gu, F., Chiessi, C. M., Zonneveld, K. A. F., and Behling, H.: Late Quaternary environmental dynamics inferred from marine sediment core GeoB6211-2 off southern Brazil, Palaeogeogr. Palaeocl., 496, 48-61, https://doi.org/10.1016/j.palaeo.2018.01.015, 2018.

Gu, F., Pätzold, J., and Behling, H.: Evidence of cooling in the tropical South Atlantic off southeastern Brazil during the last $50 \mathrm{kyr}$, Rev. Palaeobot. Palyno., 272, 104128, https://doi.org/10.1016/j.revpalbo.2019.104128, 2019.

Hardman-Mountford, N. J., Richardson, A. J., Agenbag, J. J., Hagen, E., Nykjaer, L., Shillington, F. A., and Villacastin, C.: Ocean climate of the South East Atlantic observed from satellite data and wind models, Prog. Oceanogr., 59, 181-221, https://doi.org/10.1016/j.pocean.2003.10.001, 2003.

Howe, J. N. W., Huang, K.-F., Oppo, D. W., Chiessi, C. M., Mulitza, S., Blusztajn, J., and Piotrowski, A. M.: Similar mid-depth Atlantic water mass provenance during the Last Glacial Maximum and Heinrich Stadial 1, Earth Planet. Sci. Lett., 490, 51-61, https://doi.org/10.1016/j.epsl.2018.03.006, 2018.

Hut, G.: Consultants' group meeting on stable isotope reference samples for geochemical and hydrological investigations, in: Consultants' group meeting on stable isotope reference samples for geochemical and hydrological investigations, Report to the Director General, International Atomic Energy Agency (IAEA), Vienna, Austria, available at: https://inis.iaea.org/search/search. aspx?orig_q=RN:18075746 (last access: 23 October 2019), 1987.

Jaeschke, A., Rühlemann, C., Arz, H., Heil, G., and Lohmann, G.: Coupling of millennial-scale changes in sea surface temperature and precipitation off northeastern Brazil with high-latitude climate shifts during the last glacial period, Paleoceanography, 22, 1-10, https://doi.org/10.1029/2006PA001391, 2007.

Jennerjahn, T. C., Ittekkot, V., Arz, H. W., Behling, H., Pätzold, J., and Wefer, G.: Asynchronous terrestrial and marine signals of climate change during Heinrich events, Science, 306, 22362239, https://doi.org/10.1126/science.1102490, 2004.

Kasper, S., van der Meer, M. T. J., Mets, A., Zahn, R., Sinninghe Damsté, J. S., and Schouten, S.: Salinity changes in the Agulhas leakage area recorded by stable hydrogen isotopes of $\mathrm{C}_{37}$ alkenones during Termination I and II, Clim. Past, 10, 251-260, https://doi.org/10.5194/cp-10-251-2014, 2014.

Kroopnick, P. M.: The distribution of ${ }^{13} \mathrm{C}$ of $\Sigma \mathrm{CO}_{2}$ in the world oceans, Deep-Sea Res., 32, 57-84, https://doi.org/10.1016/01980149(85)90017-2, 1985.

Lamy, F., Kaiser, J., Arz, H. W., Hebbeln, D., Ninnemann, U., Timm, O., Timmermann, A., and Toggweiler, J. R.: Modulation of the bipolar seesaw in the Southeast Pacific during Termination 1, Earth Planet. Sc. Lett., 259, 400-413, https://doi.org/10.1016/j.epsl.2007.04.040, 2007.

Lessa, D. V. O., Venancio, I. M., dos Santos, T. P., Belem, A. L., Turcq, B. J., Sifeddine, A., and Albuquerque, A. L. S.:
Holocene oscillations of Southwest Atlantic shelf circulation based on planktonic foraminifera from an upwelling system (off Cabo Frio, Southeastern Brazil), Holocene, 26, 1175-1187, https://doi.org/10.1177/0959683616638433, 2016.

Lessa, D. V. O., Santos, T. P., Venancio, I. M., and Albuquerque, A. L. S.: Offshore expansion of the Brazilian coastal upwelling zones during Marine Isotope Stage 5, Global Planet. Change, 158, 13-20, https://doi.org/10.1016/j.gloplacha.2017.09.006, 2017.

Lessa, D. V. O., Santos, T. P., Venancio, I. M., Santarosa, A. C. A., dos Santos Junior, E. C., Toledo, F. A. L., Costa, K. B., and Albuquerque, A. L. S.: Eccentricity-induced expansions of Brazilian coastal upwelling zones, Global Planet. Change, 179, 33-42, https://doi.org/10.1016/j.gloplacha.2019.05.002, 2019.

Li, M., Hinnov, L., and Kump, L.: Acycle: Time-series analysis software for paleoclimate research and education, Comput. Geosci., 127, 12-22, https://doi.org/10.1016/j.cageo.2019.02.011, 2019.

Liu, W., Xie, S.-P., Liu, Z., and Zhu, J.: Overlooked possibility of a collapsed Atlantic Meridional Overturning Circulation in warming climate, Science Advances, 3, e1601666, https://doi.org/10.1126/sciadv.1601666, 2017.

Locarnini, R. A., Mishonov, A. V., Antonov, J. I., Boyer, T. P., Garcia, H. E., Baranova, O. K., Zweng, M. M., Paver, C. R., Reagan, J. R., Johnson, D. R., Hamilton, M., and Seidov, D.: World Ocean Atlas 2013, Volume 1: Temperature, edited by: Levitus, S. and Mishonov, A., NOAA Atlas NESDIS 73, 40 pp., available at: https://www.nodc.noaa.gov/OC5/indprod.html (last access: 20 November 2019), 2013.

Lund, D. C., Tessin, A. C., Hoffman, J. L., and Schmittner, A.: Southwest Atlantic water mass evolution during the last deglaciation, Paleoceanography, 30, 477-494, https://doi.org/10.1002/2014PA002657, 2015.

Lüthi, D., Le Floch, M., Bereiter, B., Blunier, T., Barnola, J.-M., Siegenthaler, U., Raynaud, D., Jouzel, J., Fischer, H., Kawamura, K., and Stocker, T. F.: High-resolution carbon dioxide concentration record 650,000-800,000 years before present, Nature, 453, 379-382, https://doi.org/10.1038/nature06949, 2008.

Lynch-Stieglitz, J., Valley, S. G., and Schmidt, M. W.: Temperature-dependent ocean-atmosphere equilibration of carbon isotopes in surface and intermediate waters over the deglaciation, Earth Planet. Sc. Lett., 506, 466-475, https://doi.org/10.1016/j.epsl.2018.11.024, 2019.

Mendonça, L. F., Souza, R. B., Aseff, C. R. C., Pezzi, L. P., Möller, O. O., and Alves, R. C. M.: Regional modeling of the water masses and circulation annual variability at the Southern Brazilian Continental Shelf, J. Geophys. Res.-Ocean., 122, 1232-1253, https://doi.org/10.1002/2016JC011780, 2017.

Möller, O. O., Piola, A. R., Freitas, A. C., and Campos, E. J. D.: The effects of river discharge and seasonal winds on the shelf off southeastern South America, Cont. Shelf Res., 28, 1607-1624, https://doi.org/10.1016/j.csr.2008.03.012, 2008.

Mulitza, S., Boltovskoy, D., Donner, B., Meggers, H., Paul, A., and Wefer, G.: Temperature surface relationships of planktonic foraminifera collected from surface waters, Paleogeogr. Palaeocl., 202, 143-152, 2003.

Mulitza, S., Chiessi, C. M., Schefuß, E., Lippold, J., Wichmann, D., Antz, B., Mackensen, A., Paul, A., Prange, M., Rehfeld, K., Werner, M., Bickert, T., Frank, N., Kuhnert, H., Lynch-Stieglitz, J., Portilho-Ramos, R. C., 
Sawakuchi, A. O., Schulz, M., Schwenk, T., Tiedemann, R., Vahlenkamp, M., and Zhang, Y.: Synchronous and proportional deglacial changes in Atlantic meridional overturning and northeast Brazilian precipitation, Paleoceanography, 32, 622-633, https://doi.org/10.1002/2017PA003084, 2017.

Müller, P. J., Kirst, G., Ruhland, G., von Storch, I., and Rosell-Melé, A.: Calibration of the alkenone paleotemperature index $\mathrm{U}_{37}^{K^{\prime}}$ based on core-tops from the eastern South Atlantic and the global ocean $\left(60^{\circ} \mathrm{N}-60^{\circ} \mathrm{S}\right)$, Geochim. Cosmochim. Ac., 62, 17571772, https://doi.org/10.1016/S0016-7037(98)00097-0, 1998.

Nagai, R. H., Ferreira, P. A. L., Mulkherjee, S., Martins, M. V, Figueira, R. C. L., Sousa, S. H. M., and Mahiques, M. M.: Hydrodynamic controls on the distribution of surface sediments from the southeast South American continental shelf between $23^{\circ} \mathrm{S}$ and $38^{\circ} \mathrm{S}$, Cont. Shelf Res., 89, 51-60, https://doi.org/10.1016/j.csr.2013.09.016, 2014.

Novello, V. F., Cruz, F. W., Vuille, M., Stríkis, N. M., Edwards, R. L., Cheng, H., Emerick, S., de Paula, M. S., Li, X., Barreto, E. de S., Karmann, I., and Santos, R. V: A highresolution history of the South American Monsoon from Last Glacial Maximum to the Holocene, Scientific Reports, 7, 44267, https://doi.org/10.1038/srep44267, 2017.

Oliver, K. I. C., Hoogakker, B. A. A., Crowhurst, S., Henderson, G. M., Rickaby, R. E. M., Edwards, N. R., and Elderfield, H.: A synthesis of marine sediment core $\delta^{13} \mathrm{C}$ data over the last 150000 years, Clim. Past, 6, 645-673, https://doi.org/10.5194/cp-6-6452010, 2010.

Olson, D. B., Podestá, G. P., Evans, R. H., and Brown, O. B.: Temporal variations in the separation of Brazil and Malvinas Currents, Deep-Sea Res., 35, 1971-1990, https://doi.org/10.1016/0198-0149(88)90120-3, 1988.

Oppo, D. W., Curry, W. B., and Mcmanus, J. F.: What do benthic $\delta^{13} \mathrm{C}$ and $\delta^{18} \mathrm{O}$ data tell us about Atlantic circulation during Heinrich Stadial 1?, Paleoceanography, 30, 353-368, https://doi.org/10.1002/2014PA002667, 2015.

Palma, E. D., Matano, R. P., and Piola, A. R.: A numerical study of the Southwestern Atlantic Shelf circulation: Stratified ocean response to local and offshore forcing, J. Geophys. Res., 113, C11010, https://doi.org/10.1029/2007JC004720, 2008.

Peterson, R. G. and Stramma, L.: Upper-level circulation in the South Atlantic Ocean, Prog. Oceanogr., 26, 1-73, https://doi.org/10.1016/0079-6611(91)90006-8, 1991.

Pezzi, L. P., Souza, R. B., Farias, P. C., Acevedo, O., and Miller, A. J.: Air-sea interaction at the Southern Brazilian Continental Shelf: In situ observations, J. Geophys. Res.-Ocean., 121, 66716695, https://doi.org/10.1002/2016JC011774, 2016.

Piola, A. R., Campos, E. J. D., Möller, O. O., Charo, M., and Martinez, C.: Subtropical Shelf Front off eastern South America, J. Geophys. Res.-Ocean., 105, 6565-6578, https://doi.org/10.1029/1999JC000300, 2000.

Piola, A. R., Matano, R. P., Palma, E. D., Möller, O. O., and Campos, E. J. D.: The influence of the Plata River discharge on the western South Atlantic shelf, Geophys. Res. Lett., 32, L01603, https://doi.org/10.1029/2004GL021638, 2005.

Piola, A. R., Möller, O. O., Guerrero, R. A., and Campos, E. J. D.: Variability of the subtropical shelf front off eastern South America: Winter 2003 and summer 2004, Cont. Shelf Res., 28, 16391648, https://doi.org/10.1016/j.csr.2008.03.013, 2008.
Portilho-Ramos, R. da C., Ferreira, F., Calado, L., Frontalini, F., and de Toledo, M. B.: Variability of the upwelling system in the southeastern Brazilian margin for the last 110,000 years, Global Planet. Change, 135, 179-189, https://doi.org/10.1016/j.gloplacha.2015.11.003, 2015.

Portilho-Ramos, R. D. C., Pinho, T. M. L., Chiessi, C. M., and Barbosa, C. F.: Understanding the mechanisms behind high glacial productivity in the southern Brazilian margin, Clim. Past, 15, 943-955, https://doi.org/10.5194/cp-15-943-2019, 2019.

Prahl, F. G. and Wakeham, S. G.: Calibration of unsaturation patterns in long-chain ketone compositions for palaeotemperature assessment, Nature, 330, 367-369, https://doi.org/10.1038/330367a0, 1987.

Reboita, M., Rocha, R., Ambrizzi, T., and Caetano, E.: An assessment of the latent and sensible heat flux on the simulated regional climate over Southwestern South Atlantic Ocean, Clim. Dynam., 34, 873-889, https://doi.org/10.1007/s00382-009-0681-x, 2010.

Reimer, P. J., Bard, E., Bayliss, A., Beck, J. W., Blackwell, P. G., and Ramsey, C. B.: IntCal13 and Marine13 Radiocarbon Age Calibration Curves 0-50,000 Years cal BP, Radiocarbon, 55, 1869-1887, https://doi.org/10.2458/azu_js_rc.55.16947, 2013.

Roberts, J., McCave, I. N., McClymont, E. L., Kender, S., Hillenbrand, C.-D., Matano, R., Hodell, D. A., and Peck, V. L.: Deglacial changes in flow and frontal structure through the Drake Passage, Earth Planet. Sc. Lett., 474, 397-408, https://doi.org/10.1016/j.epsl.2017.07.004, 2017.

Rostek, F., Ruhland, G., Bassinot, F., Muller, P., Labeyrie, L., Lancelot, Y., and Bard, E.: Reconstructing sea surface temperature and salinity using $\mathrm{d} 18 \mathrm{O}$ and alkenone records, Nature, 364, 319-321, 1993.

Rühlemann, C., Mulitza, S., Müller, P. J., Wefer, G., and Zahn, R.: Warming of the tropical Atlantic Ocean and slowdown of thermohaline circulation during the last deglaciation, Nature, 402, 511-514, https://doi.org/10.1038/990069, 1999.

Santos, T. P., Lessa, D. O., Venancio, I. M., Chiessi, C. M., Mulitza, S., Kuhnert, H., Govin, A., Machado, T., Costa, K. B., Toledo, F., Dias, B. B., and Albuquerque, A. L. S.: Prolonged warming of the Brazil Current precedes deglaciations, Earth Planet. Sc. Lett., 463, 1-12, https://doi.org/10.1016/j.eps1.2017.01.014, 2017a.

Santos, T. P., Lessa, D. O., Venancio, I. M., and Chiessi, C. M.: The impact of the AMOC resumption in the western South Atlantic thermocline at the onset of the Last Interglacial, Geophys. Res. Lett., 44, 11547-11554, https://doi.org/10.1002/2017GL074457, $2017 b$.

Saravanan, R. and Chang, P.: Chapter 9 - Midlatitude Mesoscale Ocean-Atmosphere Interaction and Its Relevance to S2S Prediction, in: Sub-Seasonal to Seasonal Prediction, edited by: Robertson, A. W. and Vitart, F., Elsevier, 183-200, 2019.

Schlitzer, R.: Ocean Data View, available at: https://odv.awi.de/ (last access: 12 February 2020), 2017.

Schrag, D. P., Adkins, J. F., McIntyre, K., Alexander, J. L., Hodell, D. A., Charles, C. D., and McManus, J. F.: The oxygen isotopic composition of seawater during the Last Glacial Maximum, Quaternary Sci. Rev., 21, 331-342, https://doi.org/10.1016/S02773791(01)00110-X, 2002.

Sepulcre, S., Vidal, L., Tachikawa, K., Rostek, F., and Bard, E.: Sea-surface salinity variations in the northern Caribbean Sea across the Mid-Pleistocene Transition, Clim. Past, 7, 75-90, https://doi.org/10.5194/cp-7-75-2011, 2011. 
Simon, M. H., Arthur, K. L., Hall, I. R., Peeters, F. J. C., Loveday, B. R., Barker, S., Ziegler, M., and Zahn, R.: Millennial-scale Agulhas Current variability and its implications for salt-leakage through the Indian-Atlantic Ocean Gateway, Earth Planet. Sc. Lett., 383, 101-112, https://doi.org/10.1016/j.epsl.2013.09.035, 2013

Silveira, I. C. A., Foloni Neto, H., Costa, T. P., Schmidt, A. C. K., Pereira, A. F., Castro Filho, B. M., Soutelino, R. G., and Grossmann-Matheson, G. S.: Chapter 4 - Physical oceanography of Campos Basin continental slope and ocean region, in: Meteorology and Oceanography, edited by: Martins, R. P. and Grossmann-Matheson, G. S., Campus, 135-189, 2017.

Spero, H. J., Bijma, J., Lea, D. W., and Bemis, B. E.: Effect of seawater carbonate concentration on foraminiferal carbon and oxygen isotopes, Nature, 390, 497-500, https://doi.org/10.1038/37333, 1997.

Stevenson, M. R., Dias-Brito, D., Stech, J. L., and Kampel, M.: How do cold water biota arrive in a tropical bay near Rio de Janeiro, Brazil?, Cont. Shelf Res., 18, 1595-1612, https://doi.org/10.1016/S0278-4343(98)00029-6, 1998.

Stramma, L. and England, M.: On the water masses and mean circulation of the South Atlantic Ocean, J. Geophys. Res., 104, 20863-20883, https://doi.org/10.1029/1999JC900139, 1999.

Stríkis, N. M., Chiessi, C. M., Cruz, F. W., Vuille, M., Cheng, H., de Souza Barreto, E. A., Mollenhauer, G., Kasten, S., Karmann, I., Edwards, R. L., Bernal, J. P., and Sales, H. dos R.: Timing and structure of Mega-SACZ events during Heinrich Stadial 1, Geophys. Res. Lett., 42, 5477-5484, https://doi.org/10.1002/2015GL064048, 2015.

Stríkis, N. M., Cruz, F. W., Barreto, E. A. S., Naughton, F., Vuille, M., Cheng, H., Voelker, A. H. L., Zhang, H., Karmann, I., Edwards, R. L., Auler, A. S., Santos, R. V., and Sales, H. R.: South American monsoon response to iceberg discharge in the North Atlantic, P. Natl. Acad. Sci. USA, 115, 3788-3793, https://doi.org/10.1073/pnas.1717784115, 2018.

Synal, H.-A., Stocker, M., and Suter, M.: MICADAS: A new compact radiocarbon AMS system, Nucl. Instrum. Meth. B, 259, 713, https://doi.org/10.1016/j.nimb.2007.01.138, 2007.

Tessin, A. C. and Lund, D. C.: Isotopically depleted carbon in the mid-depth South Atlantic during the last deglaciation, Paleoceanography, 28, 296-306, https://doi.org/10.1002/palo.20026, 2013.

Tirabassi, G., Masoller, C., and Barreiro, M.: A study of the air-sea interaction in the South Atlantic Convergence Zone through Granger causality, Int. J. Climatol., 35, 3440-3453, https://doi.org/10.1002/joc.4218, 2015.

Venancio, I. M., Belem, A. L., dos Santos, T. H. R., Zucchi, M. do R., Azevedo, A. E. G., Capilla, R., and Albuquerque, A. L. S.: Influence of continental shelf processes in the water mass balance and productivity from stable isotope data on the Southeastern Brazilian coast, J. Mar. Syst., 139, 241-247, https://doi.org/10.1016/j.jmarsys.2014.06.009, 2014.

Venancio, I. M., Belem, A. L., Santos, T. P., Lessa, D. O., Albuquerque, A. L. S., Mulitza, S., Schulz, M., and Kucera, M.: Calcification depths of planktonic foraminifera from the southwestern Atlantic derived from oxygen isotope analyses of sediment trap material, Mar. Micropaleontol., 136, 37-50, https://doi.org/10.1016/j.marmicro.2017.08.006, 2017.
Venancio, I. M., Mulitza, S., Govin, A., Santos, T. P., Lessa, D. O., Albuquerque, A. L. S., Chiessi, C. M., Tiedemann, R., Vahlenkamp, M., Bickert, T., and Schulz, M.: Millennial- to orbital-scale responses of western equatorial Atlantic thermocline depth to changes in the trade wind system since the Last Interglacial, Paleoceanography and Paleoclimatology, 33, 14901507, https://doi.org/10.1029/2018PA003437, 2018.

Veres, D., Bazin, L., Landais, A., Toyé Mahamadou Kele, H., Lemieux-Dudon, B., Parrenin, F., Martinerie, P., Blayo, E., Blunier, T., Capron, E., Chappellaz, J., Rasmussen, S. O., Severi, M., Svensson, A., Vinther, B., and Wolff, E. W.: The Antarctic ice core chronology (AICC2012): an optimized multi-parameter and multi-site dating approach for the last 120 thousand years, Clim. Past, 9, 1733-1748, https://doi.org/10.5194/cp-9-17332013, 2013.

Waelbroeck, C., Paul, A., Kucera, M., Rosell-Melé, A., Weinelt, M., Schneider, R., Mix, A. C., Abelmann, A., Armand, L., Bard, E., Barker, S., Barrows, T. T., Benway, H., Cacho, I., Chen, M.-T., Cortijo, E., Crosta, X., de Vernal, A., Dokken, T., Duprat, J., Elderfield, H., Eynaud, F., Gersonde, R., Hayes, A., Henry, M., Hillaire-Marcel, C., Huang, C.-C., Jansen, E., Juggins, S., Kallel, N., Kiefer, T., Kienast, M., Labeyrie, L., Leclaire, H., Londeix, L., Mangin, S., Matthiessen, J., Marret, F., Meland, M., Morey, A. E., Mulitza, S., Pflaumann, U., Pisias, N. G., Radi, T., Rochon, A., Rohling, E. J., Sbaffi, L., SchäferNeth, C., Solignac, S., Spero, H., Tachikawa, K., and Turon, J.-L.: Constraints on the magnitude and patterns of ocean cooling at the Last Glacial Maximum, Nat. Geosci., 2, 127-132, https://doi.org/10.1038/ngeo411, 2009.

Zhang, Y., Chiessi, C. M., Mulitza, S., Zabel, M., Trindade, R. I. F., Hollanda, M. H. B. M., Dantas, E. L., Govin, A., Tiedemann, R., and Wefer, G.: Origin of increased terrigenous supply to the NE South American continental margin during Heinrich Stadial 1 and the Younger Dryas, Earth Planet. Sc. Lett., 432, 493-500, https://doi.org/10.1016/j.epsl.2015.09.054, 2015.

Zhang, Y., Chiessi, C. M., Mulitza, S., Sawakuchi, A. O., Häggi, C., Zabel, M., Portilho-Ramos, R. C., Schefuß, E., Crivellari, S., and Wefer, G.: Different precipitation patterns across tropical South America during Heinrich and Dansgaard-Oeschger stadials, Quaternary Sci. Rev., 177, 1-9, https://doi.org/10.1016/j.quascirev.2017.10.012, 2017.

Zweng, M. M., Reagan, J. R., Antonov, J. I., Locarnini, R. A., Mishonov, A. V., Boyer, T. P., Garcia, H. E., Baranova, O. K., Johnson, D. R., Seidov, D., and Biddle, M. M.: World Ocean Atlas 2013, Volume 2: Salinity, edited by: Levitus S. and Mishonov, A., NOAA Atlas NESDIS 74, 39 pp., available at: https:// www.nodc.noaa.gov/OC5/indprod.html (last access: 20 November 2019), 2013 